\title{
THE TREATMENT OF SEGURITY INTERESTS IN AFTER-ACQUIRED PROPERTY UNDER THE PROPOSED BANKRUPTCY ACT
}

\author{
Anthony T. Kronman $\dagger$
}

Congress is currently considering several proposals for revision of the Bankruptcy Act. ${ }^{1}$ One of the important changes ${ }^{2}$ advanced in the proposals ${ }^{3}$ is the redefinition of a "voidable preference." This concept, part of bankruptcy law for more than a century, has been part of section 60 of the present Act since

$\dagger$ Associate Professor, University of Minnesota Law School. B.A., Williams College, 1968; Ph.D., Yale University, 1972; J.D., Yale Law School, 1975.

The author wishes to thank Professor Grant Gilmore of the Yale Law School for reading and commenting on an earlier draft of this Article.

111 U.S.C. $\$ \S 1-1103$ (1970).

The proposed Act, sponsored by the Commission on the Bankruptcy Laws of the United States, was originally introduced in 1973. See H.R. 10792, 93d Cong., 1st Sess. (1973); 119 CoNG. Rec. 33445 (1973). The Commission bill has been reintroduced, see S. 236, 94th Cong., 1st Sess. (1975), H.R. 31, 94th Cong., 1st Sess. (1975); 121 Cong. Rec. 6467 (daily ed. April 22, 1975). A proposal supported by the National Conference of Bankruptcy Judges is also before Congress. See S. 235, 94th Cong., 1st Sess. (1975); H.R. 32, 94th Cong., 1st Sess. (1975); 121 Cong. Rec. S6467 (daily ed. April 22, 1975); 120 Cong. Rec. H9249 (daily ed. Sept. 12, 1974). This Article principally addresses the problems of H.R. 31. Significant differences in H.R. 32 will be mentioned in the notes.

${ }^{2}$ For a general discussion of some of the changes embodied in the proposed Bankruptcy Act, see Symposium-Bankruptcy Reform-1973, 21 U.C.L.A.L. REv. 381 (1973). The legislative history of the 1973 Act is recounted briefly in Cyr, The Bankruptcy Act of 1973: Back to the Drafting Board, 48 AM. Bankr. L.J. 45 (1974). For a more detailed consideration of some of the proposed Act's most controversial sections, see, e.g., Broude, Jurisdiction and Venue Under the Bankruptcy Act of 1973, 48 AM. BANKR. L.J. 231 (1974); Brudney, The Bankruptcy Commission's Proposed "Modifications" of the Absolute Priority Rule, 48 Am. Bankr. L.J. 305 (1974); Phelan, The Proposed Bankruptcy Administration (the "FBA")-Bureaucratic Alphabet Soup Gets a Bigger Bowl, 48 AM. Bankr. L.J. 341 (1974); Twinem, Bankruptcy Report: Some Limitations on Creditors' Rights, 29 Bus. Law. 353 (1974); Viles, Non-Revolutionary Bankruptcy Act Proposed by the National Bankruptcy Commission, 29 Bus. Law. 1117 (1974); Weintraub \& Levin, Chapter VII (Reorganizations) As Proposed by the National Bankruptcy Commission: The Widening Gap Between Theory And Reality, 47 AM. BANKR. L.J. 323 (1973).

${ }^{3}$ The proposed Act is sponsored by the Commission on the Bankruptcy Laws of the United States, which was created by the Act of July 24, 1970, Pub. L. No. 91-354, 84 Stat. 468. The Commission's mandate was to "study, analyze, evaluate and recommend changes to the [Bankruptcy] Act ... in order for such Act to reflect and adequately meet the demands of present technical, financial, and commercial activities." Id. § 1(b). The Commission submitted a report explaining its proposals. See REPORT of the CoMmission 
$1898 .{ }^{4}$ Section 60 , in its present form, gives a trustee in bankruptcy the power to set aside or avoid certain transfers by the bankrupt as preferential, and to recover the transferred assets for the benefit of the bankrupt's unsecured creditors. ${ }^{5}$ The im-

on the Bankruptcy Laws of the United States, H.R. Doc. No. 93-137, 93d Cong., 1st Sess., pt. 1 (1973) [hereinafter cited as COMMISSION REPORT].

The Commission's proposals concerning the treatment of "voidable preferences" ( $\$$ 4-607) follow closely a revision of $\S 60$ of the present Bankruptcy Act prepared for and accepted by the National Bankruptcy Conference. That revision was authored by the Conference's Committee on Coordination of the Bankruptcy Act and the Uniform Commercial Code, headed by Professor Grant Gilmore [hereinafter cited as the Gilmore Committee or the Committee]. All references in this Article to the "draftsmen" of $\$ 4-607$ are to the Gilmore Committee. See Commission REPort, supra, at 206. The proposal of the National Conference of Bankruptcy Judges contains a modified version of $\$$ 4-607.

${ }^{4}$ Lord Mansfield introduced the idea of a preference or preferential transfer into the English law of bankruptcy in Morseley v. DeMattos, 1 Burr. 467, 97 Eng. Rep. 407 (K.B. 1758). Preferences were originally conceived as a kind of fraud, see id., not unlike the classical fraudulent transfer which had been proscribed since enactment of the Statute against Fraudulent Deeds, 13 Eliz. c. 5 (1571). The original English rule focused on the intent of the debtor and broadly excepted all transfers motivated by a fear of the creditor's resort to dire process. See, e.g., Thompson v. Freeman, 1 T.R. 155, 99 Eng. Rep. 1026 (K.B. 1786); Harman v. Fishar, 1 Cowp. 117, 98 Eng. Rep. 998 (K.B. 1774). That rule, still the law in England, is embodied in the English Bankruptcy Act of 1914, 4 \& 5 Geo. 5, c.59, $\S 44$.

The concept of a preferential transfer entered American law in many nineteenth century federal and state bankruptcy acts. For an account of the role played by the concept in the state insolvency statutes that flourished during the long periods between federal enactments, see P.J. Coleman, Debtors and Creditors in America 282 n.13 (1974). At the federal level, an explicit prohibition of preferential transfers first appeared in the Bankruptcy Act of 1841, ch. 9, 5 Stat. 440 (repealed 1843). Under the influence of Justice Story, the American law of preferences gradually divorced itself from its English predecessor. According to Story, the existence of a preference should depend not upon the debtor's motives or state of mind, but upon his financial condition when he made the transfer. Everett v. Stone, 8 F. Cas. 898 (No. 4577) (C.C.D. Me. 1844); Arnold v. Maynard, 1 F. Cas. 1181 (No. 561) (C.C.D. Mass. 1842). If a transfer made while the debtor was insolvent gave a creditor an advantage over co-creditors, Story argued, it should be set aside as preferential regardless of the debtor's motive. Story's reasoning was adopted by other courts and finally was ratified by the Supreme Court in Toof v. Martin, 80 U.S. (13 Wall.) 40 (1871), a case involving the preference section of the Bankruptcy Act of 1867, ch. 176, 14 Stat. 517 (repealed 1878). Thus, what might be called the "objective" theory of preferences has long been accepted in American law.

Since 1898, the preference section of the Bankruptcy Act has been $\S 60,11$ U.S.C. $\S$ 96 (1970). Section 60 adopts the objective approach, but it contains a vestige of subjectivism in its requirement that the creditor know of his debtor's insolvency for a preference to be voidable. See note 5 infra. The proposed Act would eliminate this last remnant of the English approach, except in special cases that resemble the classical fraudulent conveyance. See Commission Report, supra note 3, at 201; note 7 infra.

For a detailed discussion of the early development of the law of preference, in England and America, see G. Glenn, 2 Fraudulent Conveyances and Preferences 654-59 (2d rev. ed. 1940).

5 Section 60a(1) of the Act of March 18, 1950, ch. 70, 64 Stat. 25, 11 U.S.C. $\$ 96(a)(1)$ (1970), defines a preference as:

a transfer, as defined in this Act, of any of the property of a debtor to or for the 
portance of section 60 has been recognized in recent years as it has become "the principal conduit for discussion of the extent to which security interests [are] (or should be) good against or voidable by the trustee in bankruptcy."6

Section $4-607^{7}$ of the Act proposed by the Commission on

benefit of a creditor for or on account of an antecedent debt, made or suffered by such debtor while insolvent and within four months before the filing by or against him of the petition initiating a proceeding under this Act, the effect of which transfer will be to enable such creditor to obtain a greater percentage of his debt than some other creditor of the same class.

Section $60 \mathrm{~b}$ of the Act of March 18, 1950, ch. 70, 64 Stat. 25, 11 U.S.C. $\S 96(\mathrm{~b})$, provides that "[a]ny such preference may be avoided by the trustee if the creditor receiving it or to be benefited thereby or his agent acting with reference thereto has, at the time when the transfer is made, reasonable cause to believe that the debtor is insolvent."

${ }^{6}$ Report of the Committee on Coordination of the Bankruptcy ACT and the UNiform Commercial Code 1 (1970) [hereinafter cited as 1970 Committee RePorT]. This Report was submitted to the National Bankruptcy Conference by the Gilmore Committee in 1970, along with its final draft proposal for a revision of $\S 60$ of the Bankruptcy Act. A review of the Committee's work and an account of its informal relationship with the Review Committee that had been appointed by the American Law Institute to study suggested changes in Article 9 of the Uniform Commercial Code, may be found in 1970 CoMmitTEE REPORT, supra, at 1-4.

For a more extended discussion of the emergence of $\S 60$ as the key section for testing the validity of security interests in bankruptcy, see G. GILMORE, 2 SECURITY INterests in Personal Property \$\$ 45.3.3-45.5 (1965) [hereinafter cited as Gilmore].

${ }^{7}$ For convenience, H.R. 31, 94th Cong., 1st Sess. $\S 4-607$ (1975), is reproduced here in its entirety:

Section 4-607 Preferences.-

(a) RIGHT To REcover.-Except as otherwise provided in this section, a trustee may recover property of the debtor transferred to pay or secure, directly or indirectly, an antecedent debt of a creditor if the transfer occurred when the debtor was insolvent and occurred either

(1) within three months before the date of the petition or,

(2) if the creditor was a member of the immediate family, a partner, an affiliate, a director, an officer, or a managing agent of or for the debtor, who had reasonable cause to believe the debtor was insolvent at the date the transfer occurred, within the period commencing one year before and ending three months before the date of the petition. The trustee shall have the burden of proving insolvency and reasonable cause to believe under this paragraph.

(b) Exceptions: Transfers of Small Amounts; Statutory Liens; NoNPREFERENTIAL EFFECrs.-The trustee may not avoid a transfer under this section if-

(1) the aggregate value of all property so transferred to a creditor other than a member of the immediate family, a partner, an affiliate, a director, an officer, or a managing agent of or for the debtor, is less than $\$ 1,000$;

(2) the transfer is a statutory or common-law lien not invalid under section 4-606 or is a transfer in satisfaction of such a lien; or

(3) the result of the transfer, tested as of the date of the petition, does not enable the creditor benefited to obtain a greater percentage of his claim than other creditors of the same class and there are no unpaid creditors of a higher class.

(c) Exceptions: Enabling Loans; Subsequent Advances.- 
the Bankruptcy Laws of the United States defines the concept of a preference and specifies which preferences are voidable by the bankrupt's trustee. Accepting as a fait accompli the use of the voidable preference as a device for testing the validity of security

(1) A security interest in property acquired by the debtor, if perfected when the debtor first acquires rights in the property or within ten days thereafter, is not voidable under this section to the extent that it secures new value previously given to enable the debtor to acquire the property. In determining the amount of new value given for such security interest, the value of any other security taken for it shall be deducted.

(2) A transfer is not voidable to the extent of new value given at the time of the transfer or at any time thereafter. In determining the amount of new value given, the value of any security taken for it shall be deducted.

(d) EXCEPTION: RECEIVABLES AND INVENTORY.-If inventory was acquired or receivables arose and became collateral covered by a security agreement, a perfected transfer of such inventory or receivables or the proceeds of either is not voidable except to the extent that the transferee has improved his position by an increase in the value of the security at the expense of the estate. The transferee has so improved his position if-

(1) the debt secured exceeds the aggregate value of all security for the debt three months before the filing of the petition or, if new value was first given under the security agreement during the three month period, on the date new value was first given; and

(2) the amount by which the debt exceeded the value of the security has been reduced or eliminated by the date of the petition. The trustee shall have the burden of proving an improvement in position by an increase in the value of security at the expense of the estate and the extent thereof.

(e) INDEMNIFYING TRANSFERS.-A trustee may recover property transferred to indemnify a surety that furnished a bond or other obligation to dissolve a lien obtained by judicial proceedings that was voidable by the trustee under subsection (a). If the value of the indemnifying property is less than the amount for which such property is indemnity, the surety may retain such property on payment of its value to the trustee. The liability of the surety under the releasing bond or other obligation shall be discharged to the extent of the value of the indemnifying property recovered by the trustee or the amount paid to the trustee.

(f) Presumption of Insolvency.-A debtor is presumed to have been insolvent throughout the three-month period before the date of the petition.

(g) Definitions.-For the purpose of this section, the following definitions are applicable:

(1) The term "antecedent debt" is a debt incurred more than five days before a transfer paying or securing the debt. The term "antecedent debt" does not include (A) a debt for personal services, (B) a debt for utilities incurred within three months of the petition, (C) a debt for inventory paid for within three months of the delivery of the goods in the ordinary course of the debtor's business, or (D) an obligation to transfer ownership arising out of a contract for the sale of property owned by the debtor and in existence either at the date the contract was entered into or at a time more than three months prior to the petition.

(2) The term "inventory" means personal property leased or furnished or held for sale or lease or to be furnished under a contract for service, raw materials, work in process, or materials used or consumed in a business. "Inven- 
interests in bankruptcy proceedings, ${ }^{8}$ the Committee draftsmen have attempted in section 4-607 to set out a general formula for determining which security interests are good in bankruptcy and which are not.

Today, consensual security interests in personal property are governed almost entirely by Article 9 of the Uniform Commercial Code. ${ }^{9}$ The terminology of Article 9 appears to conflict,

tory" includes farm products such as crops or livestock held for sale.

(3) The term "new value" means money, or money's worth in goods, services, or new credit, or the release by a transferee of property previously transferred to him in a transaction which is not voidable, but does not include an obligation substituted for an existing obligation.

(4) The term "receivable" means any right to money for the transfer or use of property or for the furnishing of services, whether or not the right has been earned by performance.

(5) The term "security agreement" means any agreement between a debtor and a transferee under which the transferee receives or retains, or is to receive or retain, an interest in property or preceeds of property to secure payment or performance of an obligation.

(6) A transfer of real property other than fixtures, but including the interest of a seller or purchaser under a contract for the sale of real property, is perfected when the transferee has acquired an interest in the property which is superior to the rights a subsequent bona fide purchaser of the property from the transferor could subsequently acquire by his purchase. A transfer of fixtures or of property other than real property is perfected when the transferee has acquired an interest in the property which is superior to the rights a subsequent judicial lien creditor could acquire in the property transferred.

(7) A transfer occurs when it takes effect between the parties if perfected at that time or within ten days thereafter. If perfected after the ten days, the transfer occurs when perfection occurs. Unless perfected within ten days, a transfer not perfected before the filing of the petition dates from a time immediately preceding such filing. A transfer does not take effect before the transferor has acquired rights in the property.

Preferences are also dealt with in H.R. 32, 94th Cong., 1st Sess. § 4-607 (1975).

${ }^{8}$ Originally, the Gilmore Committee contemplated drafting a new section that would state explicitly which security interests were valid in bankruptcy, in what order, and to what extent. See Report of Committee on Coordination of THE UNiform Commercial CODE AND the BankRuptcy ACT 6 (1967) [hereinafter cited as 1967 CoMmittee RePorT]. This report accompanied the Committee's original redraft of $\$ 60$.

Presumably, such a section would have tracked the perfection and priority rules of Article 9 itself. Despite the "theoretical merit" of this simplified approach, the Committee's members believed that this solution "came too late in the day," 1970 Commitre Report, supra note 6, at 1 . Apparently, the Committee felt that lawyers, referees, and judges had grown so accustomed to analyzing the validity of security interests in the conceptual idiom of fraudulent conveyances and voidable preferences, that a fresh approach substituting a set of straightforward rules delimiting the protection to be accorded security interests in bankruptcy for the roundabout and highly metaphysical manipulation of the ideas of fraud and preference, would do more harm than good. The Committee concluded that "[ $t]$ his accumulated and encrusted burden of history was ... too heavy to be sloughed off." 1970 Commrtee Report, supra, at 1 , and decided to attack the security interest problem by revising $\S 60$ of the Bankruptcy Act.

${ }^{9}$ Article 9 is meant to be a comprehensive statute governing the creation and protec- 
however, with the conceptual framework of section 60 , which was last fully revised in 1950, before Article 9 had become the law in any state. ${ }^{10}$ Therefore, the precise status in bankruptcy of certain Article 9 security interests has remained unclear and has generated substantial controversy. ${ }^{11}$ The warmest controversy has surrounded the Article 9 "floating lien" 12 which expressly

tion of consensual security interests in chattel property. UNIFORM CoMmERCiAL CODE $\S$ 9-102. At least some interests, however, are explicitly excluded from the Article's coverage. See, e.g., UNIForm COMMercial CODE $\$ 9$-104(a) (interests which arise or attach pursuant to a statute of the United States). For an analysis of the reasons for the special exceptions contained in $\S 9-104$, see I GiLmore, supra note $6, \S 10.7$. Besides interests specifically excluded from Article 9 coverage, there are certain "peripheral" security interests whose inclusion under Article 9 is not unambiguously certain. As a result, the precise scope of Article 9 continues to be debatable. See Coogan, Leases of Equipment and Some Other Unconventional Security Devices: An Analysis of UCC Section 1-201(37) and Article 9, 1973 Duke L.J. 909; Stroh, Peripheral Security Interests-The Expanded Net of Article 9, 22 Miami L. Rev. 67 (1967); Symposium-Subordination and the Uniform Commercial Code, 23 Bus. LAw. 33 (1967); cf. Coast Bank v. Minderhout, 61 Cal. 2d 311, 392 P.2d 265, 38 Cal. Rptr. 505 (1964) (analysis of the "negative mortgage"); Reichman, The Anti-Lien: Another Security Interest in Land, 41 U. CHI. L. Rev. 685 (1974).

${ }^{10}$ The most dramatic conflict between Article 9 and $\$ 60$ is a function of their incommensurable conceptions of "perfection." See text accompanying note 59 infra. It is also difficult to reconcile the continuing prohibition of the so-called "equitable lien" in $\S$ $60 a(6)$ with Article 9's total abolition of such liens; or the "grace period" allowed by $\S$ $60 a(7)$ with the absence of any comparable grace period under Article 9 (with the exception of purchase money security interests, Uniform Commercial Code $\S 9-301(2)$, and certain nonpossessory security interests in instruments and documents, UNIForM Commercial Code \& 9-304(4)). These and other anomalies exist not because Article 9 and $\S 60$ take consciously different approaches to basic problems of policy, but because the two statutes were drafted in "different universes of discourse," 2 GiLMORE supra note $6, \S 45.7$, at 1320 .

For an excellent recent exploration of the Article 9-Bankruptcy relationship, see Skilton, Security Interests in After-Acquired Property Under the Uniform Commercial Code, 1974 WIS. L. REv. 925.

"See text accompanying notes 31 \& 32 infra.

12 The provisions of Article 9 about which discussion of the floating lien centers include those which permit the debtor (a) to hypothecate any or all of his personal property, including after-acquired property, the lien on the property following over into "products" into which it is wrought or commingled, or "proceeds" resulting from its disposition; (b) to give present security for future advances; (c) to use with respect to any kind of collateral the "notice filing" heretofore restricted to inventory and accounts receivable; and (d) to exercise such dominion or control over the collateral as may be agreed upon between the parties.

Coogan, Article 9 of the Uniform Commercial Code: Priorities Among Secured Creditors and the "Floating Lien," 72 HARv. L. Rev. 838, 839-40 (1959) (footnotes omitted). See also 1 GILMORE, supra note 6 , § 11.7 .

The term "floating lien" is used in this Article to refer in a narrower and more specific sense to Article 9's validation of security interests in after-acquired property. See Uniform Commercial Code \$§ 9-204(1) [9-204(3) (1962 version)], 9-108. This aspect of the "floating lien," more than any other, has occasioned doubts about the validity in bankruptcy of Article 9 security interests in inventory and receivables. See text accom- 
validates a security interest in after-acquired inventory and receivables. ${ }^{13}$ During the 1960's and early 1970's, the validity of this floating lien in bankruptcy proceedings was challenged, in law reviews ${ }^{14}$ and in the courts. ${ }^{15}$

A primary goal of the draftsmen of section 4-607 was to clarify exactly the limits within which a security interest in afteracquired inventory or receivables is valid in bankruptcy. ${ }^{16}$ The description of these limits proved to be, by the draftsmen's own admission, ${ }^{17}$ their most difficult problem. Their solution is contained primarily in subsection (d) of the proposed Act's section 4-607. ${ }^{18}$

The aim of this Article is to explore the shortcomings of section 4-607(d), and to suggest ways in which the subsection might be improved to further its basic objective: a "resolution of the conflicting interests of secured and unsecured creditors in the disaster of bankruptcy which, although it might wholly satisfy neither group, might nevertheless be accepted by both groups as a reasonably satisfactory compromise."19 Before the shortcomings of section 4-607(d) are canvassed, it is necessary to understand the background against which the section was drafted.

panying notes 31 \& 32 infra. Of course, the bankruptcy consequences of other aspects of the Article 9 "floating lien" (and, in particular, of the "proceeds" provisions of $\$ 9-306$ ) have not gone unnoticed. See, e.g., Countryman, Code Security Interests in Bankruptcy, 75 Com. L.J. 269, 271-75 (1970); Gillombardo, The Treatment of Uniform Commercial Code Proceeds in Bankruptcy: A Proposed Redraft of Section 9-306, 38 U. CinN. L. REv. 1 (1969); Henson, "Proceeds" Under the Uniform Commercial Code, 65 Colum. L. Rev. 232 (1965); Kennedy, The Trustee in Bankruptcy Under the Uniform Commercial Code: Some Problems Suggested by Articles 2 and 9, 14 RutGers L. Rev. 518, 531-34 (1960).

${ }_{13}$ Uniform Commercial Code \$ 9-204(1) [9-204(3) (1962 version)] \& Comment 3.

${ }^{14}$ See notes 31-67 infra \& accompanying text.

${ }^{15}$ See notes 68-76 infra \& accompanying text.

${ }^{16}$ See 1970 CommitTEe RePORT, supra note 6, at 5-7, 15-17. The Gilmore Committee considered the problem of the status of security interests in after-acquired inventory and receivables of paramount importance. They considered the provision that became the predecessor of $\S 4-607$ (d) "the heart of the matter. It deals with the only problem in the relationship between present $\S 60$ and Article 9 which has, so far, generated not only literary controversy but a substantial amount of litigation." Id. 15-16.

17 "The most difficult problem which the Committee has wrestled with during the several years of its labors has been the appropriate treatment of so-called revolving credit arrangements secured by inventory and receivables," 1970 CommitTeE REPORT, supra note 6 , at 2 .

${ }^{18}$ H.R. 31, 94th Cong., Ist Sess. $\$ 4-607$ (1975), is reproduced at note 7 supra.

191970 CoMmitee Report, supra note 6 , at 1 . See generally text accompanying notes 102-105 infra. 


\section{The Background of Section 4-607(d)}

Section $9-204(1)^{20}$ of the Uniform Commercial Code states that with certain specified exceptions, "a security agreement may provide that any or all obligations covered by the security agreement are to be secured by after-acquired collateral." The comments to section 9-204 report that the purpose of the provision is to validate "what has been variously called the floating charge, the free-handed mortgage and the lien on a shifting stock."21

In the pre-Code period, security interests in after-acquired property received varying, but generally unfavorable, judicial treatment. ${ }^{22}$ The Code's Official Comment points out:

The widespread nineteenth century prejudice against the floating charge was based on a feeling, often inarticulate in the opinions, that a commercial borrower should not be allowed to encumber all his assets present and future, and that for the protection not only of the borrower but of his other creditors a cushion of free assets should be preserved. ${ }^{23}$

${ }^{20}$ The language of $\S 9-204(1)$ of the Code, in the 1972 version, clarifies $\S 9-204(3)$ of the 1962 version.

For a general survey and discussion of the 1972 changes, see Coogan, The New UCC Article 9, 86 HARv. L. REv. 477 (1973).

21 Uniform Commercial Code \$ 9-204, Comment 2; see id., Comment 1.

${ }_{22}$ For an excellent discussion of the early history of the treatment of security interests in after-acquired property, see Cohen \& Gerber, The After-Acquired Property Clause, 87 U. PA. L. Rev. 635 (1939). Tracing the validation of security interests in future property back to Mitchell v. Winslow, 17 F. Cas. 527 (No. 9673) (C.C.D. Me. 1843) (Story, J.), Cohen and Gerber describe and criticize the welter of limitations on such interests, including the so-called "equity," New York, and Massachusetts rules.

Professor Gilmore's account of the early history of the after-acquired property clause accords with that offered by Cohen and Gerber. See 1 GILMORE, supra note 6, $\$ \$ 2.3,2.4$.

${ }^{23}$ Uniform Commercial CODE § 9-204, Comment 2; $c$., e.g., Zartman v. First Nat'l Bank, 189 N.Y. 267, 82 N.E. 127 (1907). Zartman, trustee in bankruptcy for the Waterloo Organ Company, succeeded in invalidating the interests of the bank, holder of a mortgage on the organ company's after-acquired personal property. While saying that equity would in certain circumstances enforce such a mortgage, the court held that equity would not aid the bank because enforcement could injure unwarned unsecured creditors. The court's language, however, suggests a rationale for an even broader limitation on security interests in after-acquired inventory and receivables:

The credit extended by [the mortgagor's general, unsecured creditors] enabled the mortgagor to carry on business, and if the product of that credit [i.e., the mortgagor's entire inventory] goes to the mortgagee, not only are they helpless, but, if the law is so declared, hereafter manufacturing corporations needing credit will be helpless also. If it is understood that a corporate mortgage given by a manufacturing corporation may take everything except accounts and debts, 
Despite this judicial prejudice against security interests in afteracquired property, the need for new sources of collateral ${ }^{24}$ led to the development of legal devices that permitted a collateralstarved debtor to obtain a loan secured not only by property presently in his possession, but also by property that he would have in the future. ${ }^{25}$ According to the draftsmen, Article 9, "in

such corporations, with a mortgage outstanding, will have to do business on a cash basis or cease to do business altogether.

Id. at $271-72,82$ N.E. at 128.

24 "There have no doubt been sufficient economic reasons" stimulating the search for new collateral. UnIform Commercial CODE § 9-204, Comment 2. Professor Gilmore speculates about these reasons:

As industrialization progressed, personal rather than real property came to be the principal repository of wealth. The mortgage on Blackacre would no longer be enough to support the merchant's insatiable demand for credit and the banker's demand for security. Nor would the medieval institution of pledge suffice to take up the slack: share certificates and bonds could conveniently be pledged but obviously the equipment of the factory, the rolling stock of the railroad, the stock in trade of the merchant could not be. And yet all this property which could not be pledged because it had to be used in the borrower's business represented a nearly inexhaustible source of prime collateral for loans. The story of how the equipment and the rolling stock and the stock in trade came to be available as collateral is essentially the story of personal property security law in the nineteenth century.

1 GILMORE, supra note $6, \S 2.1$, at 25.

${ }^{25}$ Of particular importance were the Factor's Lien Acts, which were modeled closely after the former N.Y. Pers. Prop. LAw $\$ 45$ (McKinney 1962), 1911 L. of N.Y., c.326, $\$$ 1 , as amended (repeal effective 1964), and the various accounts receivable statutes that were enacted in the wake of Corn Exch. Nat'l Bank \& Trust Co. v. Klauder, 318 U.S. 434 (1943). That case upset non-notification accounts receivable financing arrangements.

Although Professor Gilmore cautioned that he could not confidently put forward the conclusion that $\S 45$ validated a floating lien arrangement, 1 GILMORE, supra note $6, \S 5.4$, at 138 , it has long been assumed that $\S 45 \mathrm{did}$, in fact, effect such a validation. Dean Harlan Fiske Stone wrote: "This statute [i.e., the 1911 version of $\S 45]$ authorized the creation of a general lien or floating charge upon merchandise including after-acquired chattels, to secure the payments of advances or commissions or other charges covered by the agreement for a lien. ..." He added that the filing provisions were cumbersome and seldom used. Stone, The "Equitable Mortgage" in New York, 20 Colum. L. Rev. 519, 532 (1920). Stone's understanding of $\S 45$ was shared by Mr. Justice Brandeis. 1 GILMore, supra, at n.8; see Benedict v. Ratner, 268 U.S. 353, 361 n.1 I (1925).

For a discussion of the origin and subsequent history of the accounts receivable statutes, see 1 GILMORE, supra, §§ 8.6-8.8. It is most important to note that

most of the statutes as they were originally drafted, were either not clear that future claims could be presently assigned or were clear that they could not be. Both the statutory definitions of "account" and (under filing statutes) the filing provisions seemed to be relevant to the question: to make things a little worse, the definitional section and the filing section sometimes seemed to point firmly in different directions. The cases mostly held that future claims could not be assigned-either they were not "accounts" or they were not protected by the filing system. In several states such holdings-or the threat of them-led to further legislative amendment; thus by the end of the period, it had become crystal- 
expressly validating the floating charge, merely recognizes an existing state of things." 26

Although section 9-204 speaks of "after-acquired collateral" generally and would therefore apply when the collateral is a relatively fixed or long-term asset (such as plant equipment), ${ }^{27}$ the section's greatest impact would appear to be upon financing transactions in which the collateral is composed of assets classified as "current" or "quick" (such as inventory or receivables). ${ }^{28}$ Current assets are by nature transient: the ongoing life of a business enterprise requires their continuous liquidation. A business holds inventory in order to sell it. In the ordinary course of business, inventory is sold and transformed into accounts receivable (or intangibles of some other sort); accounts receivable are paid and the proceeds used in the purchase of fresh inventory; and the entire cycle is begun again. Stagnation at any point is usually a symptom or a cause of commercial failure.

clear in a few jurisdictions that future claims could be presently assigned-at least if they were statutory "accounts."

Id. $\$ 8.7$, at $280-81$ (emphasis supplied) (footnotes omitted).

${ }^{26}$ UNiform Cominercial Code $\$ 9-204$, Comment 2.

${ }^{27}$ See notes 155 \& 156 infra \& accompanying text. One of the consequences of the case law development following Benedict v. Ratner, 268 U.S. 353 (1925), was the "divorcement between financing on the security of long-term assets and financing on the security of . . 'quick assets'," I GrLmoRe, supra note $6, \S 8.5$, at 267 . The divorcement occurred because courts construed the Benedict holding to mean that retention by the debtor of a power to sell or otherwise dispose freely of even a portion of the collateral securing his creditor's claim "pervades and taints the instrument as a whole," rendering ineffective the creditor's security interest in any of the collateral covered by the instrument. See Brown v. Leo, 12 F.2d 350, 351 (2d Cir. 1926) (L. Hand, J.). But cf. American S.S. Co. v. Wickwire Spencer Steel Co., 42 F.2d 886 (W.D.N.Y. 1930), aff'd per curiam, 49 F.2d 766 (2d Cir. 1931).

${ }^{28}$ The "current assets" of a business enterprise include "Cash, Receivables that will become cash, and Inventories which at a little later date may become first Receivables and then Cash." T. Fiflis \& H. Kripke, Accounting for Business LawYers 56 (1971). Elsewhere, Professor Kripke has written:

Because of this accountant's classification and because each item of inventory and each account receivable is itself of short duration, these types of assets are sometimes thought of as ephemeral. ... [But] the accountant's classification, when we take it too literally, leads us astray and conceals from us the permanent long-term fixed character of the investment of a business enterprise in its normal inventory and in its normal amount of accounts receivable. The enterprise needs long-term capital for these purposes just as much as it needs long-term capital for its plant and machinery, which the accountant recognizes as fixed assets.

Kripke, Current Assets Financing as a Source of Long-Term Capital, 36 Minn. L. Rev. 506, 510-11 (1952). 
A loan secured by volatile collateral of this type must not impede the normal metamorphosis of assets from inventory to receivables to cash to inventory. The debtor must be free ro liquidate the collateral securing the debt as his business requires; in order to keep the debt fully secured, however, fresh collateral of the same sort as the old collateral ${ }^{29}$ must take the latter's place as it is liquidated. This requires a revolving collateral scheme, which depends upon the recognition and protection of security interests in after-acquired property. A principal aim of the Article 9 floating lien is to provide a legal foundation for current assets financing, that is, for financing on the basis of inventory and receivables. ${ }^{30}$

In the early 1960's, a considerable debate flared up, first in the law reviews and then in the courts, ${ }^{31}$ about the validity in bankruptcy proceedings of the Article 9 floating lien. Those who denied the validity of the lien argued that it rested upon a security interest in after-acquired property which was vulnerable to attack by the bankrupt's trustee as a voidable preference under section 60 of the Bankruptcy Act. Those who defended the validity of the lien argued that a properly perfected security interest in after-acquired property was non-preferential and therefore could not be set aside in favor of the debtor's unsecured creditors by a trustee exercising his powers under section 60 . The fundamental issue on which resolution of this dispute hinged can be understood most easily by an example.

At $\mathrm{t}_{1}$, five months prior to the filing of the bankruptcy petition, $A$ and $B$ enter into a security agreement ${ }^{32}$ in which $A$ agrees

${ }^{29}$ Of course, what collateral is "of the same sort" will depend on the specificity with which the collateral is described in the financing statement. Section 9-402(1) of the Uniform Commercial Code provides that a financing statement is sufficient if it contains "a statement indicating the types, or describing the items, of collateral." For certain goods, additional detail may be necessary. See $\$ 9-402(3)$. Section 9-110 states that for purposes of Article 9, "any description of personal property or real estate is sufficient whether or not it is specific if it reasonably identifies what is described." As to whether a financing statement purporting to cover after-acquired property must include a clause reporting that coverage, see 1 GILMORE, supra note $6, \S 11.6$, at 357.

30 "The Article 9 draftsmen read their history to say that, in fact, the after-acquired property interest, as well as inventory and receivables financing, was here to stay. What was true in fact should be stated as law and all vestiges of the old theory should be ruthlessly cut away." 1 GILMORE, supra note $6, \S 11.6$, at 355 .

${ }^{31}$ See notes 39-79 infra \& accompanying text.

${ }^{32}$ Section 9-105(1)(1) [\$ 9-105(1)(h) (1962 version)] defines a "security agreement" as "an agreement which creates or provides for a security interest." By distinguishing security interest and security agreement, "the Code makes two terms grow where one grew before." 1 GILMORE, supra note $6, \S 11.4$, at 346 . 
to lend $B \$ 75,000$. The loan is to be repaid in three installments at six month intervals. The loan is secured by a security interest in $B$ 's entire inventory, valued at $t_{1}$ at $\$ 100,000$. In addition, the security agreement contains a provision that the loan is to be further secured by any and all inventory that $B$ may acquire in the future, and that the value of the inventory securing the loan shall not in any case fall below $\$ 100,000$. If it does, $A$ has the option of treating as due and payable at once the entire amount of the loan then outstanding. At $\mathrm{t}_{1}, A$ gives $B \$ 75,000$, receives in return $B$ 's note for the full amount plus interest, and files a complete financing statement $\mathrm{t}^{33}$ with the proper state office.

Five months later, $B$ files a voluntary petition asking to be adjudicated a bankrupt. ${ }^{34}$ At the time of the petition he has on hand inventory worth $\$ 100,000$ and little else. None of the inventory items held by $B$ when he files his petition were in his possession at t. He has come into possession of, or, more precisely, he has "acquired rights" 35 in, all of them during the four-month period immediately preceding bankruptcy. During this entire four-month period, $B$ has been insolvent, and $A$ has known of $B$ 's insolvency. $A$ files a secured claim ${ }^{36}$ asserting a valid security interest in the inventory. $B$ 's trustee challenges the claim on the grounds that $A$ 's interest in the inventory constitutes a voidable preference under section 60 . Should $A$ prevail against $B$ 's trustee?

All but one of the elements of a preference ${ }^{37}$ have clearly been built into this example. The crucial question is whether the last element, transfer for an "antecedent debt," is present. We may assume that $B$ 's debt to $A$ was incurred at $\mathrm{t}_{1}$, when $A$ lent $B$ the $\$ 75,000 .^{38}$ But when did the transfer occur in which $B$ gave $A$ the security interest which $A$ now claims in $B$ 's presently owned inventory? If this transfer occured at $\mathrm{t}_{\mathbf{1}}$, it was not for an antece-

${ }^{33}$ In general, Article 9 provides that non-possessory security interests must be perfected by filing. UNIFORM COMMercial CODE $\$$ 9-302(1). The secured party must file a "financing statement." The formal requisites of the financing statement are detailed in $\S$ 9-402; the proper place for filing, in $\$ 9-401$.

${ }^{34}$ See $\S 4$ (a) of the Bankruptcy Act, 11 U.S.C. $\$ 22(a)$ (1970).

${ }^{35}$ See UNIFORM COMmercial CODE $\S 9-203(1)(c)$. For a discussion of the importance of this subsection for the preference problem, see text accompanying notes 45-48 infra.

${ }^{36}$ See $\$ 57$ (a) of the Bankruptcy Act, 11 U.S.C. § 93(a) (1970).

${ }^{37}$ See note 5 supra.

${ }^{38}$ Under the "substitution of collateral" theory, it is argued that $B$ incurs an additional debt to $A$ each time an item of inventory is sold off and replaced. See note 58 infra \& accompanying text. 
dent but for a contemporaneous debt. But if the transfer did not occur until $B$ acquired rights in the individual items that $A$ now claims as collateral for his loan, then each such transfer was for an antecedent debt and therefore voidable. The disputed validity in bankruptcy of the Article 9 floating lien was thought to depend upon this question of chronology: When $\operatorname{did} B$ 's transfer to $A$ of a security interest in $B$ 's after-acquired property take place?

\section{A. The Attack upon the Floating Lien}

Those who contended that the transfer took place when the debtor acquired rights in the collateral and was therefore for an antecedent debt relied primarily on the following analysis. ${ }^{39} \mathrm{Ac}-$ cording to section 9-303, "a security interest is perfected when it has attached and when all of the applicable steps required for perfection have been taken."40 For a security interest to be perfected, section 9-303 requires that the secured party have complied with whatever requirements were applicable, such as the filing requirement, ${ }^{41}$ the possession requirement, ${ }^{42}$ or the special rules governing the perfection of security interests in instruments, documents, and goods covered by documents ${ }^{43}$ or governing the perfection of security interests in proceeds. ${ }^{44}$ In addition, the security interest claimed by the secured party must have "attached." Prior to attachment the security interest is not, and cannot be, fully perfected. ${ }^{45}$

Section 9-203(1) provides that a security interest cannot attach unless and until: "(a) the collateral is in the possession of the

\footnotetext{
${ }^{39}$ See, e.g., Countryman, supra note 12, at 277 (1970); Gordon, The Security Interest in Inventory Under Article 9 of the Uniform Commercial Code and the Preference Problem, 62 Colum. L. Rev. 49 (1962); King, Section 9-108 of the Uniform Commercial Code: Does It Insulate the Security Interest from Attack by a Trustee in Bankruptcy?, 114 U. PA. L. REv. 1117 (1966); Riemer, Bankruptcy-Preference-Conflict Between Section 9-108 of the Uniform Commercial Code and Section 60(a) of the Bankruptcy Act, 70 Com. L.J. 63 (1965).

${ }^{40}$ UNIFORM Commercial CODE $\$ 9-303(1)$.

${ }^{41}$ Id. § 9-302.

${ }^{42} I d . \S 9-305$.

${ }^{43} I d . \S 9-304$.

${ }^{44} I d . \S 9-306$.

${ }^{45}$ The idea of "attachment" and the distinction between attachment and perfection are novel aspects of Article 9. Professor Gilmore has suggested that the concept of attachment was introduced to satisfy Karl Llewellyn's appetite for metaphysical clarity. The draftsmen considered the concept "harmless, obvious and of merely theoretical interest." 1 GILMORE, supra note $6, \S 11.5$, at 352 . That this assessment was inaccurate is amply borne out by the way the critics of the Article 9 floating lien have used the concept of attachment to argue that the transfer of a security interest in after-acquired property
} 
secured party pursuant to agreement, or the debtor has signed a security agreement which contains a description of the collateral ... and (b) value has been given; and (c) the debtor has rights in the collateral." 46

In the hypothetical posed above, $B$ (the debtor) acquired all of his rights in the inventory held at the time of bankruptcy during the preceding four-month period. Consequently, $A$ 's security interest in these individual inventory items must have attached during the four-month preference period. As a result, $A$ 's security interest in the inventory that he now claims as collateral was perfected well after his initial loan to $B$ and within the preference period defined by section 60 . Finally-and this is the most important but weakest ${ }^{47}$ link in the argument-the transfer from $B$ to $A$ of a security interest in $B$ 's collateral cannot have occurred before $A$ 's security interest achieved full perfection as defined by section 9-303. Before then, $A$ only had $B$ 's promise that he would transfer to $A$ a security interest in new inventory, should he acquire any; $B$ had not actually transferred such a security interest, nor could he, until he himself acquired rights in the collateral. It is obvious, it was argued, that $B$ could not transfer to $A$ a legal entitlement to property in which he had no right or interest at the time of the alleged "transfer." 48

Oddly enough, section 9-108, which was intended to protect security interests in after-acquired property, makes this argu-

is a transfer for an antecedent debt. As a result, friends of the floating lien have suggested that the idea of attachment be eliminated from Article 9 and that perfection be tied directly to filing and the giving of value.

The idea of when a security interest 'attaches' does not seem to have much utility, although it does make explicit that there must be an obligation and agreement. Why not delete the reference to the debtor's rights in the collateral? Why could not perfection (incorporating sections 9-303 and 9-204) depend on the existence of a security agreement, an obligation (value) and filing (or whatever other steps for perfection are required)?

King, supra note 39, at 1132. See also 42 N.Y.U.L. REv. 150 (1967).

${ }^{46}$ Uniform Commercial Code § 9-203(1).

${ }^{47}$ See text accompanying notes 59-61 infra.

48 "[U]ntil the debtor acquired some interest in the future goods they belonged entirely to someone else and, consequently, any interest the debtor purported to create in them could not have been a transfer of his property. When such goods were finally acquired, the creditor's loan, made sometime before, was in fact an antecedent obligation of the debtor." Gordon, supra note 39 , at 70 (footnote omitted).

Professor Countryman, argues that this view coincides with the pre-Code position, that "no lien, legal or equitable, can be created until the goods [are] acquired by the bankrupt," citing Union Trust Co. v. Townshend, 101 F.2d 903 (4th Cir.), cert. denied, 307 U.S. 646 (1939), and Irving Trust Co. v. Commercial Factors Corp., 68 F.2d 864, 868-69 (2d Cir. 1934). Countryman, supra note 12, at 275. 
ment more plausible. ${ }^{49}$ The section explicitly states that a security interest in after-acquired collateral "shall be deemed to be taken for new value and not as security for an antecedent debt." ${ }^{\text {00 }}$ Such wording arguably demonstrates that the draftsmen assumed that the time of transfer of a security interest would otherwise be the time of attachment. Having conceded the point, the draftsmen failed to provide an effective cure. ${ }^{51}$ The Bankruptcy Act looks to state law, ${ }^{52}$ here the Uniform Commercial Code, to determine when a security interest is so far perfected that it may be said to be transferred. But whether a transfer fixed by state law at $t_{1}$ was for an antecedent debt is quite a different question, and one which the Bankruptcy Act does not leave open. Instead, the Act tacitly incorporates a common sense test of antecedence: whether the debt was incurred prior to $t_{1} .^{\mathbf{5 3}}$

49 For a discussion of the impact of Uniform Commercial CODE $\S 9-108$ on the preference problem, see P. Coogan, W. Hogan \& D. Vagts, 1 Secured Transactions UNDER THE UNIFORM COMMERCIAL CODE 1207-16 (1963); 2 GilmoRe, supra note 6, § 45.6; Ashe, [The Bankruptcy Act Vis-a-Vis the Uniform Commercial Code] Part 2-The Floating Lien Under UCC 9-108 New Consideration or Antecedent Debt, 75 Com. L.J. 61 (1970); Countryman, supra note 12, at 276; Friedman, The Bankruptcy Preference Challenge to After-Acquired Property Clauses Under the Code, 108 U. PA. L. REv. 194 (1959); Riemer, supra note 39.

50 Uniform Commercial Code § 9-108.

51 The conclusion of one writer was that $\$ 9-108$ " $(1)$ is probably unnecessary; (2) is quite likely self-defeating; (3) attempts, however, to bring about a commercially desirable result; and (4) should be rewritten or amended to effectuate this result." Friedman, supra note 49 , at 197 .

52 For an exhaustive discussion of the role played by state law in bankruptcy proceedings, see Countryman, The Use of State Law in Bankruptcy Cases (pts. 1, 2), 47 N.Y.U.L. Rev. 407, 631 (1972). According to Professor Countryman:

Originally, and to a large extent still, section 60 embodies a purely federal bankruptcy concept, although it will usually be state law that determines (1) the events which constitute a transfer as defined in section $1(30)$, (2) the assets owned and liabilities owed by the debtor which will establish whether he was insolvent as defined in section 1(19) when the transfer occurred, (3) whether the transferee was a creditor with an antecedent debt within the meaning of section 60 , and (4) whether the transferee was already fully secured so that the effect of the transfer was not to prefer him over other unsecured or partially secured creditors within the meaning of section 60 . But, while section 60 thus looks to state law to determine the events on which it operates, . . . the meaning of the operative terms of section 60 , such as 'transfer' and 'antecedent debt' is a federal Id. 632 . question....

${ }^{53}$ If the statement in the Code comment [to $\$$ 9-108] that, "The determination of when a transfer is for antecedent debt is largely left by the Bankruptcy Act to state law" is supposed to mean that state law may define the meaning of "antecedent." I know of no authority for the proposition and I doubt that the man who wrote the sentence knows of any either. A more accurate statement would be that the Bankruptcy Act in $\$ 60$ and elsewhere leaves to other law, usually state law, the determination when a debt is created and when a transfer 
In attempting to "deem" this test out of existence, one critic has argued, ${ }^{54}$ section 9-108 exceeds the authority left to state law by the Bankruptcy Act and must give way to the superior federal statute. ${ }^{55}$ As a result, section 9-108 fails to insulate security interests in after-acquired property from attack as preferential transfers.

\section{B. The Defense of the Floating Lien}

The defenders of the Article 9 floating lien offered a variety of arguments in rebuttal. Their first two arguments, remarkably abstract, were designed to show that the transfer by a debtor of a security interest in his after-acquired property is not for an antecedent debt at all, but rather for a debt incurred simultaneously with the transfer.

\section{One argument, based upon the "entity" theory," accom-}

occurs-save as perfection provisions in $\S 60$ and elsewhere provide that the transfer is not deemed made for bankruptcy purposes until perfected against specified third parties. Once those two times are established, the bankruptcy court has never needed any help-and, I believe, is not authorized to take any help-from state law to determine whether one time is antecedent to the other. Countryman, supra note 12, at 276 (footnotes omitted).

54 Countryman, supra note 52 , at 635 .

55 "What constitutes a transfer and when it is complete within the meaning of $\$ 60$ (a) of the Bankruptcy Act is necessarily a federal question, since it arises under a federal statute intended to have uniform application throughout the United States." McKenzie v. Irving Trust Co., 323 U.S. 365, 369-70 (1945).

56 The "entity" or "unitary" theory was first (and perhaps most clearly) formulated by Chief Judge Magruder in Manchester Nat'l Bank v. Roche, 186 F.2d 827 (1st Cir. 1951), a case involving the assignment of after-acquired accounts under the New Hampshire Factors' Lien Act, N.H. Laws 1943, c. 161, amended, N.H. Laws 1949, c. 156 (repeal effective 1961). Judge Magruder's vivid formulation was admittedly pure dictum, contrary to the applicable statute. According to Judge Magruder,

[I]t might be possible to treat a merchant's accounts receivable as a unit presently and continuously in existence, the component elements of which (the particular accounts) may be constantly changing, without affecting the identity of the res; so that a general assignment by way of security of accounts receivable present and future might be deemed to create in praesenti a lien upon this enduring unit, the accounts receivable, which lien would persist as a floating charge upon such res, however much its component elements might change from time to time by the payment of old accounts and the creation of new ones. Id. at 831 .

The most fervent proponent of the "entity" theory in recent years has been Ray Henson. See Henson, supra note 12, at 232-37. It has been suggested, however, that the "entity" theory is "hopelessly inconsistent" with the atomistic language of UNIFORM Commercial Code $\$ 9-204(2)(d)$ (1962 version) which provides that a security interest in an account cannot attach "until [the account] comes into existence." 65 MicH. L. REv. 1004, 1007 (1967). But see 2 GILMORE, supra note 6, § 45.5.

Another argument advanced against the "entity" theory, on policy grounds, is that it is 
plished this result with a bit of metaphysical ${ }^{57}$ sleight of hand, by moving back the transfer of the security interest in the debtor's after-acquired property to the time of the initial loan $\left(t_{1}\right)$. The "entity" advocates insisted that the collateral underlying a loan secured by inventory or receivables consists not of the individual goods or claims possessed by the debtor at $t_{1}$, but rather the continuous stream of assets whose general contours (that is, whose overall financial value) remain constant despite the continual replacement of its component parts. There is, it was argued, no after-acquired property problem at all, because the collateral securing the loan remains unchanged. There is only one transfer of a security interest in the continuing "res" of the debtor's inventory or receivables, rather than a series of temporally discrete transfers, each occurring as the debtor acquires rights in a new item of inventory or a new account. This single transfer occurs at $\mathrm{t}_{1}$ and is for a contemporaneous, not an antecedent, debt.

The second argument in support of the validity of the Article 9 floating lien conceptually shifted forward the time at which the debt is incurred. Accepting the proposition that the transfer of a security interest in after-acquired property occurs when the debtor acquires rights in individual items composing the collateral, this theory held that new value is transferred from the secured party to the debtor at the same time. According to proponents of this view, ${ }^{58}$ the secured party's assent to his

too blunt a tool for properly balancing the interests of secured and unsecured creditors, since it may approve the kind of conduct that the preference law historically condemns, i.e., the conscious and deliberate transfer of property to a favored creditor within four months of bankruptcy [for example, through the use of crash sales of inventory to feed a lien on receivables].

Hogan, Games Lauyers Play with the Bankruptcy Preference Challenge to Accounts and Inventory Financing, 53 CORNELl L. REv. 553, 561 (1968).

The "entity" theory is most compelling when the collateral involved is composed of many individual items that replace each other with great rapidity. When the collateral is composed of a few items which are "turned over" at lengthy intervals, the theory is inappropriate. See 15 U.C.L.A. L. REv. 678, 697 (1968).

${ }^{57}$ See Henson, supra note 12 at 233: "The paradox of Heraclitus is applicable to the flow of inventory into proceeds and back again: you cannot step twice into the same river ... The paradox suggests the process of change in all life." See G. Kirk \& J. Raven, The Presocratic Philosophers 196-97 (1962); Plato, Cratylus 673 (B. Jowett ed. 1871).

58 This so-called "substitution of collateral" doctrine has been expounded and defended in numerous law review articles. See, e.g., Hogan, supra note 56, at 561-63; Krause, Kripke, \& Seligson, The Code and the Bankruptcy Act: Three Views on Preferences and After-Acquired Property, 42 N.Y.U.L. Rev. 278, 282 (1967); Note, After-Acquired Property 
debtor's liquidation of the collateral (by selling the inventory or collecting the accounts), and to the debtor's use of the proceeds as he sees fit, itself constitutes fresh consideration supporting subjection of new collateral to the lender's security interest. Once again the transfer of a security interest is for a contemporaneous debt. As with the "entity" theory, the antecedence problem is conceptualized away.

The third and perhaps most popular argument supporting the Article 9 floating lien turns upon analysis of the different perfection requirements of section $60 \mathrm{a}(2)$ of the Bankruptcy $\mathrm{Act}^{59}$ and section 303 of Article $9 .^{60}$ Under the Bankruptcy Act, a transfer takes place when a security interest is so far perfected that no subsequent lien, obtainable in a judicial proceeding on a simple contract, can become superior to that interest. The Act

Security Interests in Bankruptcy: A Substitution of Collateral Defense of the U.C.C., 77 YALE L.J. 139 (1967). The Note anticipates $\$ 4-607$ (d) of the proposed Bankruptcy Act in pointing out that "[i]t has long been held that a mere substitution or exchange of property is not preferential except to the extent that the value of the creditor's interest in the substituted property exceeds the value of the creditor's interest in the original property," id. 146, and in advocating a two-point test for measuring preferential transfers, id. 151-58. The "substitution of collateral" doctrine has also had its critics. See, e.g., Countryman, supra note 12, at 277.

The doctrine's origin appears to be in the line of "net result" cases, which held that no Section 60 preference results from payments by a debtor to a supplier of goods, even where such payments are not contemporaneous with delivery, if they are part of a bona fide system of open account on running credit, and there is no net diminution of the debtor's estate within the four-month period taken as a whole.

Note, supra, at 155 n.69. See, e.g., Jaquith v. Alden, 189 U.S. 78 (1903); In re Fred Stern \& Co. 54 F.2d 478 (2d Cir. 1931); In re Stewart, 233 F. Supp. 89 (D. Ore. 1964). Perhaps the most frequently quoted of these cases is In re Pusey, Maynes, Breish Co., 122 F.2d 606, 608 (3d Cir. 1941), which held that an assignment of new accounts during the four-month period immediately preceding bankruptcy does not constitute a voidable preference, despite the fact that "the withdrawal and substitution of security" are not simultaneous. (The court added that "in a proper case the excess, i.e., the difference in value between the new security and the old, [might constitute] a preference to that extent.") For a compilation of the relevant cases, see 3 ColLIER ON BANKRUPTCY II 60.20 , 60.21 (14th ed. 1975). that

59 Section $60 \mathrm{a}(2)$ of the Bankruptcy Act, 11 U.S.C. \$ 96(a)(2) (1970), provides in part,

for the purposes of subdivisions a and $b$ of $[\$ 60]$, a transfer of property other than real property shall be deemed to have been made or suffered at the time when it became so far perfected that no subsequent lien upon such property obtainable by legal or equitable proceedings on a simple contract could become superior to the rights of the transferee.

60 Uniform Commercial Code § 9-303.

See Friedman, supra note 49 , at $218-19$. This argument has been followed by many of the courts that have held Article 9 security interests in after-acquired property immune from attack under $\S 60$ of the Bankruptcy Act. See note 73 infra. 
does not demand the state of absolute perfection, including attachment, ${ }^{61}$ defined by section $9-303$. The process of perfection may reach the stage necessary for a transfer under the Act prior to perfection under Article 9.

In our hypothetical, a lien creditor would have nothing to attach after the financing statement was filed but before $B$ acquired rights in the collateral. As soon as $B$ acquires those rights, $A$ 's security interest attaches, before any lien creditor has had an opportunity to make a prior attachment. Even if the lien and security interest attached simultaneously, the lien would not be superior to the security interest, only equal or inferior to it. This situation does not contravene the requirements of section $60 \mathrm{a}(2)$. Thus, the security interest in after-acquired property reaches the proper level of perfection at the time of filing, not the time of attachment.

When the Bankruptcy Act states a substantive definition or rule of law, such as the section $60 \mathrm{a}(2)$ perfection test, inconsistent or conflicting state rules must give way. By applying the section $60 \mathrm{a}(2)$ perfection test to our hypothetical situation, we arrive at the conclusion that, for bankruptcy purposes, the security interest in the debtor's after-acquired property was sufficiently perfected at $t_{1}$ to be deemed transferred at $t_{1}$, that is, for a contemporaneous debt.

Proponents of the Article 9 floating lien insisted that the three technical arguments just reviewed derive additional strength from two policy considerations based upon legislative intent. First, we are told, ${ }^{62}$ the draftsmen of Article 9 wanted to facilitate inventory and accounts receivable financing by giving express statutory support to the floating lien arrangement. In doing so, they did not intend to make possible an arrangement that had been impossible before. They were merely streamlining, and thereby reducing the transaction costs of, a type of financing that previously had required complicated and expensive techniques. ${ }^{63}$ Commercial good sense would dictate upholding the validity in bankruptcy of the Article 9 floating lien unless

"See text accompanying note 40 supra.

621 Gilmore, supra note $6, \$ 11.6$, at $355,359$.

63 "[C] the process, and it does so without harming anyone." $65 \mathrm{Mich}$. L. Rev. 1004, 1012-13 (1967). A sophisticated financer was required to go to great lengths under the pre-Code law to insure that his security interest in revolving collateral would be subject neither to 
strong policy considerations, in addition to technical reasons, dictated otherwise.

Secondly, it was argued, the legislative history of section 60 reveals that the draftsmen never intended to strike down inventory and accounts receivable financing. ${ }^{64}$ The real thrust of section 60 in both its 1938 and 1950 versions was to destroy the "equitable pledge."65 Unfortunately, the 1938 bona fide pur-

the dominion rule of Benedict v. Ratner, 268 U.S. 353 (1925), nor to invalidation because of the after-acquired character of the collateral. See, e.g., In re New Haven Clock \& Watch Co., 253 F.2d 577 (2d Cir. 1958).

64 Nothing in the legislative history of either the 1938 or 1950 amendments to $\$ 60$ indicates that the evil sought to be eliminated was the security interest in after-acquired property. Indeed, Professor MacLachlan, who authored the 1938 amendment, stated that "we are not saying you cannot make a mortgage on after-acquired property. What we do say is that a lien is not regarded as made for the purpose of the law of preference ... until it is so far perfected as to be good as against a bona-fide purchaser." Hearings on H.R. 6439 \& H.R. 8046 Before the House Comm. on the Judiciary, 75th Cong., 1st Sess., ser. 9, at 123 (1937) [hereinafter cited as Revision Hearings].

The "bona fide purchaser" test incorporated in the 1938 version of $\$ 60$, Act of June 22,1938 , ch. 575,52 Stat. 869 , as amended, 11 U.S.C. $\$ 96$ (1970), was scaled down in 1950 to the "judicial lien creditor" test that appears in present $\S 60 \mathrm{a}(2)$. Act of March 18 , 1950 , ch. $70, \S 1,64$ Stat. 24 . In its report explaining the 1950 changes, the House Committee on the Judiciary emphasized that the Chandler Amendment of 1938 tended "to impede and choke the flow of credit, principally to small-businessmen." H.R. REP. No. 1293, 81 st Cong., 1st Sess. 4 (1949). To relieve the crimp in the flow of commercial credit, caused by the 1938 amendment of $\S 60$ and aggravated by the interpretation of that section in Corn Exch. Nat'l Bank \& Trust Co. v. Klauder, 318 U.S. 434 (1943), the 1950 revision of $\S 60$ sought to make clear that "no transfer made in good faith, for a new present consideration [which the Committee left undefined], shall constitute a preference ... if the provisions of applicable State law governing the perfection of such transfer are complied with." H.R. REP. No. 1293, 81st Cong., 1st Sess. 6 (1949).

The view of the author of the 1938 amendment was "that $\$ 60$ was not intended to apply to transactions like those authorized by article 9." 65 MICH. L. REv. 1004, 1011 n.38 (1967).

${ }_{65}$ The voidable preference section in the Bankruptcy Act of 1898, ch. $51, \S 60,30$ Stat. 562, did not contain a test for determining at what time a transfer was made for bankruptcy purposes. This omission became a matter of congressional concern following a series of Supreme Court cases upholding the validity in bankruptcy of the "secret lien" or "equitable pledge." See Carey v. Donohue, 240 U.S. 430 (1916); Sexton v. Kessler, 225 U.S. 90 (1912); Humphrey v. Tatman, 198 U.S. 91 (1905); Thompson v. Fairbanks, 196 U.S. 516 (1905). Under these decisions, a creditor with a non-possessory security interest in his debtor's property, who had not filed or otherwise notified third parties, could successfully perfect his security interest even on the eve of his debtor's bankruptcy (usually by taking physical possession of the collateral itself). Such a creditor would prevail over third-party claimants who had not even known, prior to the debtor's collapse into insolvency, of the existence of the creditor's interest in the collateral. Congress felt that the result in these cases was wrong. Its remedy was revision of the voidable preference section of the Bankruptcy Act to make clear that for bankruptcy purposes, the transfer in the typical "equitable pledge" situation occurs when the security interest is perfected, and does not "relate back" to the time of the original-and, by definition, private-agreement between the secured creditor and his debtor. Early amendments which sought to achieve 
chaser test killed not only the equitable pledge but nearly all legitimate forms of accounts receivable and inventory financing as well. ${ }^{66}$ The reversion in 1950 to a judicial lien creditor test reflected the bankruptcy bar's honest if belated realization that the real culprit was the unrecorded mortgage (on inventory, receivables, equipment, or other) and not the floating lien per $s e{ }^{67}$

this result failed of their purpose. See Act of Feb. 5, 1903, ch. 487, 32 Stat. 799, amended, Act of June 25, 1910, ch. 412, 36 Stat. 842, amended, Act of May 27, 1926, ch. 406, 44 Stat. 666, as amended, 11 U.S.C. $\$ 96$ (1970). These amendments, and the case law interpreting them, are discussed in 3 CoLliER ON BANKRUPTCY, supra note 4, 760.37 .

The 1938 amendment of $\S 60$ once again sought to eliminate "equitable" liens of the Sexton v. Kessler variety. See Revision Hearings, supra note 64, ser. 9, at 123. As the testimony of the chief draftsman of the 1938 amendment makes clear, the revised version of $\S 60$, with its "bona fide purchaser" test, was intended to reach the Kessler or Thompson situation, but not to invalidate properly perfected security interests in after-acquired property. Id. In the latter case, the filing required for proper perfection would put third parties on notice of the secured creditor's claim and presumably would obviate the need for further legislative action.

Unfortunately, the scope of the 1938 amendment reached considerably beyond the intentions of its draftsmen. See note 66 infra. To facilitate the flow of credit to small businessmen, whose capital structure often made inventory and non-notification accounts receivable financing especially attractive, $\$ 60$ of the Bankruptcy Act was amended once again in 1950. The 1950 amendment substituted a "judicial lien creditor" test for the "bona fide purchaser" test in the 1938 version of $\$ 60 \mathrm{a}(2)$ and added a new subsection (6) which declared the recognition of equitable liens "to be contrary to the policy of this section." The purpose of these changes was to reverse the trend following Corn Exch. Nat'l Bank \& Trust Co. v. Klauder, 318 U.S. 434 (1943), while retaining the Chandler Amendment's prohibition of secret liens of the Thompson and Kessler sort. H.R. REP. No. 1293, 81st Cong., Ist Sess. 4-6 (1949). See also MacLachlan, Preference Redefined, 63 Harv. L. REv. 1390 (1950).

${ }^{66}$ In the entire history of statutory drafting, the 1938 revision of $\S 60$ is the classical example of overkill. It presently appeared that the draftsmen, taking dead aim at Sexton $v$. Kessler, had also brought down non-notification accounts receivable financing arrangements in a great many states and, in all probability, all inventory financing arrangements in all states. The reason why the revision was effective to strike down Sexton $v$. Kessler and like cases was that the common law rule about imperfect pledges, on which the bankruptcy rule was vaguely based, had been that good faith purchasers from the pledgor before delivery took free of the "equitable pledgee's" interest. The unpremeditated destruction resulted from the facts that in all inventory financing buyers take free of the security interest and that, in so-called English rule states, the assignee of a chose in action who did not notify the obligor of his assignment could lose to a later assignee. Thus such arrangements could never be perfected against potential "bona fide purchasers" and consequently could always be avoided as preferences (since, at the date of filing the bankruptcy petition, the debtor would be, by necessary hypothesis, insolvent and known to be so).

2 GILMORE, supra note $6, \S 45.3 .3$, at 1302.

${ }^{67}$ See notes 64 \& 65 supra.

Section 60 of the Bankruptcy Act was never intended to invalidate the floating lien recognized by section 9-108 of the UCC. The purpose of the Chandler Act amendment was to invalidate the unrecorded equitable interest in Sexton $v$. Kessler, of which subsequent creditors had no notice. The legislative history of 
Since Article 9 expressly validates the floating lien, and since it has never been the aim of section 60 to invalidate the lien, one distorts the basic objectives of both statutes by construing the Article 9 security interest in after-acquired property as a voidable preference.

\section{The Developing Case Law}

All of these arguments, for and against the validity of the Article 9 floating lien in bankruptcy, had been debated exhaustively by the time the first case involving the issue was decided. ${ }^{68}$ A series of cases $^{69}$ litigating this precise issue followed in rapid

the act reveals no concern with the automatic lien on after-acquired inventory or receivables, a basic security device in the financing industry.

44 TEXAs L. Rev. 1369, 1377 (1966).

${ }^{68}$ Rosenberg v. Rudnick, 262 F. Supp. 635 (D. Mass. 1967), noted in 20 ALA. L. REv. 135 (1967), 29 Onо ST. L.J. 790 (1968), and 15 U.C.L.A.L. REv. 678 (1968). Rosenberg involved the validity in bankruptcy of a properly filed Article 9 security interest in after-acquired inventory. The bankrupt's trustee argued that under $\S 9-303$, a security interest in after-acquired property is perfected only when the interest "attaches," and that attachment cannot occur before the debtor acquires rights in the collateral. In rejecting this argument, the court held that "[p]erfection under state law need not be full perfection but only perfection so far as is necessary to meet the test of $\S 60(a)(2)$." $262 \mathrm{~F}$. Supp. at 638 . Sufficient perfection was attained when Rudnick filed his financing statement. Id.

The court stressed that the $\$ 9-108$ definition of antecedent debt should be accepted because it is in accord with current business practice, and that the provisions of Article 9 concerning perfection and attachment should not be read to demand a contrary result. The court also emphasized that the lien involved, although on after-acquired property, was not "secret," and that Rudnick had not made an illicit effort to "outrace" other creditors. For these reasons, the court concluded that its holding would not frustrate the policy objectives of $\S 60$.

${ }^{69}$ In re Portland Newspaper Publishing Co., 271 F. Supp. 395 (D. Ore. 1967), aff'd sub nom. DuBay v. Williams, 417 F.2d 1277 (9th Cir. 1969); In re White, 283 F. Supp. 208 (S.D. Ohio 1967); Grain Merchants v. Union Bank \& Sav. Co., 408 F.2d 209 (7th Cir. 1969); Biggins v. Southwest Bank, 322 F. Supp. 62 (S.D. Cal. 1971), aff'd, 490 F.2d 1304 (9th Cir. 1973); In re Nickerson \& Nickerson, Inc., 329 F. Supp. 93 (D. Neb. 1971), aff'd per curiam, 452 F.2d 56 (8th Cir. 1971); In re King-Porter Co., 446 F.2d 722 (5th Cir. 1971); Owen v. McKesson \& Robbins Drug Co., 349 F. Supp. 1327 (N.D. Fla. 1972), aff'd mem., 486 F.2d 1401 (5th Cir. 1973); E.F. Corp. v. Smith, 496 F.2d 826 (10th Cir. 1974); In re Wilco Forest Mach., Inc., 491 F.2d 1041 (5th Cir. 1974).

Of these cases, the most widely discussed were the Portland Newspaper case, noted in 22 ARk. L. Rev. 501 (1968), 1 GA. L. Rev. 257 (1967), 28 MD. L. Rev. 78 (1968), 65 Mich. L. Rev. 1004 (1967), 42 N.Y.U.L. Rev. 150 (1967), 44 TeXAs L. Rev, 1369 (1966), 16 U. KAN. L. Rev. 394 (1968), and 1968 Wrs. L. Rev. 246; and the Grain Merchants case, noted in 64 Nw. L. Rev. 705 (1969) and 23 Sw. L.J. 745 (1969).

In Portland Newspaper many members of the local printers' unions had lost their jobs as a result of an unsuccessful strike against Portland's two largest newspapers. To provide their members with employment, the unions themselves organized and published a rival newspaper, the Portland Reporter. The unions also formed the Rose City Development Company, which leased equipment and made loans to the Reporter. These loans were 
succession. In all but one ${ }^{70}$ the courts concluded that a properly recorded Article 9 security interest in after-acquired property could not be set aside as a voidable preference under section 60. More often than not, this conclusion was supported not by one argument, but by a host of arguments drawn from the basic

secured by a lien on the Reporter's then existing and after-acquired accounts receivabie. Rose City made a proper Article 9 filing when the loans were made. Two years later the Reporter was adjudicated bankrupt, and Rose City filed a claim asserting its security interest in the bankrupt's accounts receivable.

The Reporter's trustee in bankruptcy argued that the transfer of an Article 9 security interest cannot take place before the interest's attachment (which was specified as the time the account "comes into existence," Uniform Commercial Code \$ 9-204(2)(d) (1962 version)). As a result, the trustee argued, Rose City's security interest in any account arising after the filing of its financing statement was transferred for an antecedent debt. The referee in bankruptcy accepted this argument, but both the district court and the court of appeals rejected it. Writing for the Ninth Circuit, Judge Hufstedler declared:

Congress did not state that a "transfer" occurs when a security interest attaches or when state law says a conveyance has been made. Congress provided that a transfer is "deemed" to have been made when it became "so far perfected" that no subsequent lien creditor could achieve priority. "Transfer" for the purpose of section $60 \mathrm{a}(2)$ is thus equated with the act by which priority over later creditors is achieved and not with the event which attaches the security interest to a specific amount.

We look to state law, therefore, only to decide the point at which Rose City's claim to the future accounts was sufficiently asserted to prevent a subsequent lien creditor from achieving priority over it in those accounts. That time was the date upon which Rose City filed its financing statement . . . . Because Rose City filed its financing statement long before the four-month period anteceding bankruptcy, its security interest is immune from the trustee's preference challenge. DuBay v. Williams, 417 F.2d 1277, 1287-88 (9th Cir. 1969).

The Grain Merchants case also involved the status of a properly filed Article 9 security interest in after-acquired accounts, but arose in a more traditional commercial setting than did the Portland Newspaper case. The bankrupt's trustee repeated the argument of the Reporter trustee. In rejecting his theory, the court in Grain Merchants held that perfection, for $\S 60 \mathrm{a}(2)$ purposes, occurs when a security interest in after-acquired property is filed. The court also made use of the "entity" theory, see note 56 supra, and the "substitution of collateral" doctrine, see note 58 supra.

${ }^{70}$ E.F. Corp. v. Smith, 496 F.2d 826 (10th Cir. 1974). In that case, Elmer Fox \& Co., a certified accounting firm, had rendered services periodically for the bankrupt. In November, 1971, to secure $\$ 20,000$ already owed to Fox and to provide security for contemplated future services, the bankrupt gave Fox a note for $\$ 40,149.44$ and a chattel mortgage on certain oil properties that it owned. By the time of bankruptcy, in May, 1972 , the November, $1971 \mathrm{debt}$ had been reduced to $\$ 8,000$. During the four-month period immediately preceding bankruptcy, however, Fox had performed additional services for the bankrupt for which it had not received full compensation. Fox claimed that its chattel mortgage secured both the $\$ 8,000$ debt and the monies owing for its services to the bankrupt during the four-month preference period. The referee's decision to allow the first claim but to disallow the second one was upheld by the district court and the Court of Appeals for the Tenth Circuit.

The court of appeals began by noting that $\S 9-303(1)$ provides that a security interest cannot be perfected before it has attached, and that $\$ 9-204$ (1) stipulates that a security interest cannot attach until "value is given." Id. at 830 . It then concluded that because 
catalogue outlined above. The "entity" theory, ${ }^{71}$ the "substitution of collateral" doctrine, ${ }^{72}$ the primacy of the section $60 \mathrm{a}(2)$ perfection test, ${ }^{73}$ and commercial good sense ${ }^{74}$ were all invoked, in some cases by the same court, ${ }^{75}$ to explain why an Article 9 floating lien is valid in bankruptcy. Such a plethora of justifica-

$\overline{\text { Fox }}$ "was not bound in November, 1971, to perform future accounting services," he did not give value until "the services were performed ... . Accordingly, there was no relation back to the November transaction and the claim of secured status falls." Id. at 831 .

The court was careful to distinguish Portland Newspaper and Grain Merchants:

In those cases money had been lent and the question was whether the security interest attached to items which came into existence within the four-month period. Our situation is different. We are not concerned with the nature and extent of the security interest but rather with the right of the creditor to a preferred status on the basis of personal services rendered within the four-month period....

$\ldots$

We see no conflict between this result [i.e., the result in E.F. Corp.] and the holdings in the accounts receivable and after-acquired inventory cases. In those cases the benefit had been received by the bankrupt before the four-month cutoff. In the instant case it had not. To permit relation back of a claim for voluntary personal services within the four-month period would provide a loop hole which, in our opinion, was not intended by either the Bankruptcy Act or the Uniform Commercial Code.

Id.

The court's reasoning in E.F. Corp. is unsound. To the extent that it was held invalid, the bankrupt's transfer to Fox of a security interest in its oil properties was not a transfer for an antecedent debt at all. It was a "future advance," made in return for a consideration received by the transferor subsequently, see 3 CoLLIER ON BANKRUPTCY supra note 58, I 60.19, therefore falling entirely outside the ambit of $\S 60$. Besides, Article 9 explicitly provides that "[o]bligations covered by a security agreement may include future advances or other value whether or not the advances or value are given pursuant to commitment . . . " Uniform Commercial Code $\$ 9-204(3)$ [\$ 9-204(5) (1962 version)]. Confirmatory agreements, at the time value is given, are unnecessary. Id., Comment 5.

Because it carefully distinguishes Portland Newspaper and Grain Merchants, and because its own analysis is so murky, E.F. Corp. should not be read as in any way qualifying the otherwise universal judicial acceptance of the validity in bankruptcy of the Article 9 security interest in after-acquired property.

${ }^{71}$ Grain Merchants v. Union Bank \& Sav. Co., 408 F.2d 209, 215-17 (7th Cir. 1969);

In re Nickerson \& Nickerson, Inc., 329.F. Supp. 93, 96 (D. Neb. 1971).

${ }^{72}$ Grain Merchants v. Union Bank \& Sav. Co., 408 F.2d 209, 217-18 (7th Cir. 1969).

${ }^{73}$ In re Wilco Forest Mach., Inc., 491 F.2d 1041, 1046-47 (5th Cir. 1974); In re King-Porter Co., 446 F.2d 722, 730 (5th Cir. 1971); DuBay v. Williams, 417 F.2d 1277, 1287-88 (9th Cir. 1969); Grain Merchants v. Union Bank \& Sav. Co., 408 F.2d 209, 212-15 (7th Cir. 1969); Owen v. McKesson \& Robbins Drug Co., 349 F. Supp. 1327, 1331-32 (N.D. Fla. 1972); Rosenberg v. Rudnick, 262 F. Supp. 635, 638 (D. Mass. 1967).

${ }^{74}$ In re King-Porter Co., 446 F.2d 722, 732 (5th Cir. 1971); In re Portland Newspaper Publishing Co., 271 F. Supp. 395, 400 (D. Ore.), aff'd sub nom. DuBay v. Williams, 417 F.2d 1277 (9th Cir. 1967); Rosenberg v. Rudnick, 262 F. Supp. 635, 639 (D. Mass. 1967).

${ }^{75}$ In re King-Porter Co., 446 F.2d 722 (5th Cir. 1971); Grain Merchants v. Union Bank \& Sav. Co., 408 F.2d 209 (7th Cir. 1969); Rosenberg v. Rudnick, 262 F. Supp. 635 (D. Mass. 1967). See generally Healy, The Floating Lien Controversy in the Courts: Judicial Response to the Preference Problem, 10 B.C. IND. \& CoM. L. Rev. 265 (1969). 
tions may evidence judicial misgivings about the persuasiveness of any single argument. Despite this equivocation about why an Article 9 floating lien should be insulated from attack under section 60 , a clear judicial consensus emerged that it should be so insulated.

When the draftsmen of section 4-607 of the proposed revision of the Bankruptcy Act began their work in 1966, the extensive law review literature had already raised considerable doubt about the validity in bankruptcy of any Article 9 security interest in after-acquired inventory or receivables. At first, the draftsmen apparently felt that section 60 should be redrafted to make clear that such a security interest is not a voidable preference. ${ }^{76}$ As the debate moved into the courts, it became clear that the draftsmen's initial fears were groundless.

In fact, the pendulum had begun to swing the other way: The Article 9 floating lien on inventory and receivables was so well-received by the courts that the real danger soon appeared to be that secured parties might take "blanket liens on all the present and future personal property of their debtors, make no further advances and sleep peacefully in the assurance that, on bankruptcy day, all the assets will come to them."77

Although the original concern of the draftsmen of section 4-607 had been protection of the secured party who provided financing on the basis of after-acquired inventory and receivables, their project gradually metamorphosed into a "rescue mission for unsecured creditors." 78 As a result, the Committee was obliged to reevaluate the competing interests of secured and unsecured creditors in bankruptcy proceedings, and to attempt "a fair and sensible resolution of the underlying policy issues."79

\section{Security Interests in After-Acquired Property Under Subsection 4-607(d)}

The voidable preference section of the proposed Bankruptcy Act is section 4-607..$^{80}$ The section's basic structure is rela-

${ }^{76}$ Note 8 supra.

771970 Committee Report, supra note 6, at 6.

${ }^{78}$ Id.

${ }^{79}$ Id. 7.

${ }^{80}$ For the text of this section of the bill, H.R. 31, 94th Cong., Ist Sess. $\$ 4-607$ (1975), see note 7 supra. All references in the text are to this legislation. For an account of the proposals now before Congress, see note 1 supra. 
tively simple. Subsection (a), the operative subsection, gives the bankrupt's trustee the right to recover property that was (1) transferred by the bankrupt to pay or secure an antecedent debt, during the three month period preceding the filing of the petition and while the bankrupt was insolvent, or (2) transferred to any one of a group of specified "insiders," to pay or secure an antecedent debt, while the bankrupt was insolvent and the transferee had "reasonable cause to believe" he was insolvent, during the period "commencing one year before and ending three months before the date of the petition." 81

Subsections (b), (c), and (d) state exceptions to the general rule of subsection (a). ${ }^{82}$ Subsection (e ${ }^{83}$ deals with the avoidance by the trustee of certain indemnifying transfers by the bankrupt to his surety; subsection $(f)^{84}$ states a presumption regarding the bankrupt's insolvency during the three-month period preceding the filing of the petition; and the last subsection, $(\mathrm{g}),{ }^{85}$ defines several of the most important terms used in section 4-607.

Section 4-607's treatment of security interests in afteracquired property generates problems in at least four areas. First, the language of subsection (g)(1) leaves a major gap in the structure of the Act, opening the possibility that security in-

${ }^{81} \mathrm{Id}$.

H.R. 32, 94th Cong., 1st Sess. § 4-607(a) (1975), differs in several respects. The old preference period of four months is retained for most cases. For insider transfers, a preference during the year prior to the petition requires proof only of simple insolvency and not also that the insider have had reasonable cause to believe that the debtor was insolvent.

Under H.R. 31, 94th Cong., 1st Sess. (1975), the trustee benefits from a presumption of the debtor's insolvency, $\S 4-607(f)$, during the three months prior to the petition; but in the nine-month period preceding that, for insider transfers, the trustee has the "burden of proving" both insolvency and reasonable cause to believe, § 4-607(a)(2). Under H.R. 32, the trustee has both the presumption of insolvency, \& 4-607(g), and the burden of proving insolvency in the four-month preference period, $\$ 4-607(a)(2)$. During the eight months prior to that, the insider transferee has the burden of proof. The combination of $\$ \S 4-607(a)(2)$ and $(g)$ in H.R. 32 would be a sure breeder of litigation.

82 H.R. 32, 94th Cong., 1st Sess. (1975), omits § 4-607(b)(1) of H.R. 31, 94th Cong., 1st Sess. (1975), which provides that certain transfers of small aggregate amounts to a creditor are not voidable. H.R. 32 also adds an exception to an exception in its $\$ 4-607(\mathrm{e})$.

${ }^{83}$ Section 4-607(f) in H.R. 32, 94th Cong., lst Sess. (1975).

${ }^{84}$ Sections $4-607(\mathrm{~g})$ in H.R. 32, 94th Cong., Ist Sess. (1975). The presumption extends for four rather than three months. But see id. \$ 4-607(a)(2).

${ }^{85}$ Sections $4-607(\mathrm{~g})(1)-(5)$ of H,R. 31, 94th Cong., 1st Sess. (1975) are $\S \S$ 4-607(h)(1)-(5) of H.R. 32. Section 4-607(h)(1) of H.R. 32 lengthens the "grace period"-in which a debt, though chronologically earlier, is not antecedent-from five to thirty days. It also omits certain exclusions provided in H.R. 31. Sections 4-607(g)(6)-(7) of H.R. 31 are $\S \S 4-6.07(i)(1)-(2)$ of H.R. 32. 
terests in after-acquired property will receive too much protection from avoidance by a trustee. Second, section 4-607(d), which carves out exceptions to the avoidance power of the trustee, presents too rigid a test for inventory-and-receivables improvements that are voidable; it may curtail important, and fair, forms of financing. Third, section 4-607 does not consider the status of subsequent appreciation in the value of property subject to a security interest. Finally, the section unjustifiably accords less favorable treatment to collateral composed of long-term or fixed assets than to short-term collateral such as inventory or receivables. This Article aims to remedy these defects by proposing amendments and additions to the section.

\section{A. Time of Transfer}

\section{The Transfer and the Petition}

Under the voidable preference sections of both the present and proposed Acts, the time of a transfer that the trustee wishes to avoid must be fixed in relation to the bankruptcy petition to determine both the applicability of the preference period and the point at which insolvency must be established. The time of the transfer must also be fixed in relation to the debt that it pays or secures in order to resolve the issue of antecedence.

Under present law, section $60 \mathrm{a}(2)^{86}$ fixes the time at which a transfer is made or suffered, apparently ${ }^{87}$ for all purposes, ${ }^{88}$ in terms of the process of perfection. The draftsmen of the proposed Act, however, have at least partially abandoned reliance on the process of perfection as the test for determining the time of transfer. Section 4-607(a) states that the time for measuring the proximity of the transfer to the petition, and for testing the debtor's solvency, is the time at which the transfer "occurred." "Occurred" is used here as a term of art. The definitional section of 4-607 states that a transfer "occurs" when it both "takes effect" and is "perfected." 89 Furthermore, a transfer does not

${ }^{86}$ For the text of $\S 60 \mathrm{a}(2)$, see note 59 supra.

${ }^{87}$ See DuBay v. Williams, 417 F.2d 1277 (9th Cir. 1969).

${ }^{88}$ See notes 68-75 supra \& accompanying text.

${ }^{89}$ H.R. 31, 94th Cong., 1st Sess. § 4-607(g)(7) (1975). Section 4-607(g)(7) includes certain "relation back" provisions. If perfection takes place within ten days after the transfer takes effect, then the transfer is deemed to occur when it takes effect. If per- 
"take effect" until the transferor acquires rights in the property. Thus, the transfer of a security interest in after-acquired property cannot "occur" before the debtor has acquired rights in the property itself. In effect, the draftsmen of the proposed Act have incorporated section 9-203(1) of the Uniform Commercial Code, requiring the debtor's acquisition of rights for "attachment" of a security interest, as part of the test for determining the temporal proximity of the transfer to the bankruptcy petition.

According to $4-607(\mathrm{~g})(7)$, for a transfer to "occur" it must both "take effect" and be "perfected." Under the proposed Act, the perfection of a transfer is to be determined by a formula slightly though significantly different from that imbedded in section $60 \mathrm{a}(2)$. The present law states that a transfer is deemed to be made or suffered when no subsequent lien "obtainable by legal or equitable proceedings on a simple contract" can be superior to the transferred interest..$^{90}$ Under the $60 \mathrm{a}(2)$ test, the "obtainable" lien must be "superior" to the interest transferred in order to prevent the interest's perfection. ${ }^{91}$ The proposed Act, however, states that the transferred interest is perfected only when it is superior. ${ }^{92}$ Thus, where a lien could attach at the same time the transfer "takes effect," if the transferee has taken all other steps necessary for perfection, the present Bankruptcy Act deems the transfer perfected, and the proposed Act deems it unperfected.

This difference has important consequences for the treatment of security interests in after-acquired property. Under state law, a lien obtained after the filing of a financing statement and the creation of a consensual security agreement can attach to after-acquired property simultaneously with the attachment of the consensual security interest itself. ${ }^{93}$ It could therefore be argued that under the proposed Act, a security interest in afteracquired property cannot be perfected in the bankruptcy sense until the security interest has "attached," because at any point

fected later, the transfer occurs simultaneously with perfection. If the transfer has taken effect but has not been perfected when a petition is filed, the transfer generally "dates" from a time immediately prior to the filing of the petition.

${ }^{90} 11$ U.S.C. $\$ 96(a)(2)(1970)$.

${ }^{91}$ See notes 59-61 supra \& accompanying text.

${ }^{92}$ H.R. 31, 94th Cong., 1st Sess., § 4-607(g)(6) (1975).

${ }^{93}$ See 1970 Committee Report, supra note 6, at 19-20. 
prior to that a judicial lien creditor theoretically could acquire an equal interest in the after-acquired property.

Thus, the language of section 4-607 states that a security interest in after-acquired property cannot "take effect" until it has attached, and strongly implies that such a security interest cannot be perfected prior to attachment. Since a transfer "occurs" only when it "takes effect" and is perfected, two independent reasons appear to support the proposition that under the proposed Act, the transfer of a properly filed security interest in after-acquired property cannot occur prior to its attachment. ${ }^{94}$

\section{The Transfer and the Debt}

"Antecedent debt" is a defined term of art in the proposed Act. It is generally "a debt incurred more than five days before a transfer paying or securing the debt." 95 Unfortunately this definition begs the crucial question: When does a transfer pay or secure the debt? Does the definition refer to the time of "occurrence," of "effectiveness," or of "perfection"? Or does the Act adopt the time of transfer as defined by state law? If the pro-

94 Of course, one might try to revive the "entity" argument to sustain a floating lien. See notes $56 \& 57$ supra \& accompanying text. The debtor, it would be argued, acquired rights in an entity called "inventory" at the time of or prior to the filing of a security agreement; thus, the transfer took effect at the time of filing. The argument has significant flaws. While the debtor's acquisition of rights is necessary to effectiveness, it may not be sufficient. Secondly, related supporting arguments for floating liens are not available here. The substitution of collateral theory, for example, is not applicable because moving forward the time of incurring the debt still places the transfer within the preference period and makes it voidable. Thirdly, the structure of the proposed Act and its practical approach preclude such abstract theorizing. The Act itself provides for exceptions when it deems them warranted; and because the Act was drafted with the Uniform Commercial Code in mind, the problem of construing statutes drafted in "diverse universes," see note 10 supra, no longer exists.

One would also have to attempt to hurdle the second line of defense, the new test of perfection. Because perfection turns on whether more than one lien or interest can attach at a single moment, a court might be convinced that it was presented with a typical second-before, second-after problem, see generally, e.g., Haskins, Dower in Mortgaged Property, 5 Miami L. Rev. 187, 191-93 (1951), and find the possibility of equal claims remote enough to make the security interest superior to all conceivable liens and thus perfected. Indeed, slight changes in the proposed Act would foreclose such metaphysical legerdemain and assure that only those security interests in after-acquired property specifically excepted would survive. While the likelihood of success for such conceptualization may be deemed slight and changes therefore unnecessary, these slight changes are set forth at note 99 infra.

${ }^{95}$ H.R. 31, 94th Cong., 1st Sess. $\$ 4-607(\mathrm{~g})(1)$ (1975). This provision also contains several types of debt which are deemed never to be antecedent. H.R. 32, 94th Cong., 1st Sess. (1975) contains a more limited exclusion, and provides for thirty days rather than five. 
posal is left unaltered, only extensive litigation will resolve the question.

Under the language of the proposal as now written, the most natural solution would be to say that the draftsmen meant the time of transfer employed for determining antecedence to be the same as that used for measuring the proximity of the transfer to the bankruptcy petition; namely, the time of "occurrence." On this reading, since a transfer cannot "occur" until it "takes effect," and cannot take effect until the transferor has rights in the property, a security interest in after-acquired property must be, by definition, a transfer for antecedent debt. ${ }^{96}$

To read antecedence as depending on the time the transfer "takes effect" between the parties, rather than on the time it "occurs," leads to undesirable results. A transfer may "take effect" between two parties before being perfected and therefore binding upon third parties. ${ }^{97}$ Thus suppose $X$ lends $Y$ a sum of money in exchange for which $X$ takes a security interest in $Y$ 's yacht. $X$ and $Y$ enter into a security agreement at the time $Y$ incurs the debt, but $X$ fails to file a financing statement. The transfer has "taken effect" between the parties, although $X$ has not perfected his security interest. On the eve of $Y$ 's bankruptcy a year later, $X$ finally perfects his security interest by filing a proper financing statement. If a transfer pays or secures when it "takes effect" between the parties, $X$ 's security interest in $Y$ 's yacht will have been transferred to $X$ at the time he made his loan to $Y$ and entered a security agreement with him. It will have been transferred for a contemporaneous rather than an antecedent debt. This result is undesirable because it would allow secured parties to maintain secret liens and circumvent the operation of the voidable preference section of the proposed Act.

Equally strong reasons support rejecting the suggestion that "a transfer paying or securing" means "the perfection of a trans-

${ }^{96}$ A creditor here might invoke not only the "entity" theory, see notes 56 \& 57 supra $\&$ accompanying text, but also the "substitution of collateral" argument, see note 58 supra \& accompanying text, to circumvent a finding of antecedence. But here again the lack of policy support and the diminished necessity of accommodating statutes drafted in "diverse universes" would undermine such conceptualiztion. See generally note 94 supra.

${ }^{97}$ When a transfer takes effect is defined in terms of a negative and a contingency. At a minimum, effectiveness requires that the debtor have rights in the collateral, H.R. 31, 94th Cong., 1st Sess. $§ 4-607(\mathrm{~g})(7)$ (1975), but effectiveness is not dependent on perfection and may take place prior to perfection. Id. The Act provides no further definition. 
fer paying or securing." If the definition of antecedence in the proposed Act is construed as referring to the time a transfer is perfected, courts might again begin conceptualizing perfection so as to permit security interests in after-acquired property, even without an explicit statutory authorization such as section 4-607(d). ${ }^{98}$ This result would simply make hash of the entire statutory scheme that 4-607 sets out for the treatment of afteracquired inventory and receivables. Subsection 4-607(d) states an exception to the general rule of 4-607(a). The exception says that certain transfers of a security interest in after-acquired inventory or receivables are not voidable by the transferor's trustee in bankruptcy, implying that absent such an exception all transfers of this sort would be recoverable by a trustee exercising his avoidance powers under 4-607(a). This implication, in turn, makes sense only if all transfers of a security interest in afteracquired inventory or receivables are transfers for an antecedent debt. ${ }^{99}$

The definition of antecedence that best accords with the policy aims and technical structure of the proposed Act is one that focuses, in the Act's own language, upon the time at which a transfer occurs, rather than the time at which it is perfected or "takes effect" between the parties. In order to make the defini-

${ }^{98}$ See note 94 supra \& note 99 infra.

49 To make absolutely clear that all conceptual support for floating liens is washed away, except for the exceptions of $\$ 4-607(d)$, some commentators may wish to substitute the following for subsections $(\mathrm{g})(6)$ and $(\mathrm{g})(7)$ and add a subsection $(\mathrm{g})(8)$ :

$4-607(\mathrm{~g})(6)$ A transfer of property occurs (1) when the transfer is perfected and (2) the transferor has acquired rights in the discrete property which is the subject of the transfer or in the discrete property a security interest in which is the subject of the transfer.

(7) A transfer of real property other than fixtures, but including the interest of a seller or purchaser under a contract for the sale of real property, is perfected when the transferee has acquired an interest in the property which is superior to and not only equal to the rights a subsequent bona fide purchaser of the property from the transferor could subsequently acquire by his purchase. A transfer of fixtures or of property other than real property is perfected when the transferee has acquired an interest in the property which is superior to and not only equal to the rights a subsequent judicial lien creditor could acquire in the property transferred.

(8) A transfer shall be deemed to have occurred from the time it took effect between the parties, if perfected within ten days thereafter. Otherwise, a transfer shall not occur until a transfer is perfected. A transfer not perfected before the filing of the petition dates from a time immediately preceding such filing. A transfer does not take effect before the transferor has acquired rights in the property. 
tion of antecedence crystal-clear, and to integrate it better with the technical vocabulary of section $4-607$, the first sentence of subsection $(\mathrm{g})(1)$ should be redrafted to read:

The term "antecedent debt" means a debt incurred more than five days before the occurrence of a transfer paying or securing the debt.

\section{B. The Two-Point "Net Improvement" Test}

The debate over the validity in bankruptcy of the Article 9 security interest in after-acquired inventory and receivables has centered on various technical considerations involving the interrelated concepts of perfection and antecedence. ${ }^{100}$ This profusion of technical arguments has obscured the conflicting material interests at stake. The conflict, of course, is between the bankrupt's secured and unsecured creditors. ${ }^{101}$

A secured party, by definition, wants to be treated as a special creditor who is entitled to full satisfaction of his claim out of the collateral securing it before other creditors, especially unsecured creditors, can apply any of this collateral to the satisfaction of their claims. ${ }^{102}$ The secured creditor demands privileged treatment in his debtor's bankruptcy; he insists that the prospect of privileged status in the awful event of insolvency was one of the factors inducing him to make his loan in the first place. ${ }^{103}$

${ }^{100}$ See notes 39-62 supra \& accompanying text.

101 This conflict has long been at the very center of bankruptcy administration. See 2 GiLMORE, supra note $6, \S 45.2$.

"In the structure of the [Bankruptcy Act] there is a sort of built-in tension between the basic prescription that security rights are to be recognized and the administrative procedures which insure that they will be recognized to the smallest degree possible." Id. 1287.

102 See Uniform Commercial Code $\$ 9-504$.

103 "The acid test as to the validity of the security interest is its ability to withstand attack by the trustee in bankruptcy of the debtor, because the trustee embodies in his person the rights of almost everyone who can challenge the validity of a security interest." Coogan \& Vagts, The Secured Creditor and the Bankruptcy Act: An Introduction, in 1 P. Coogan, W. Hogan, \& D. Vagts, supra note 49, at 972.

If everything goes well, it turns out that the security was never really needed, except for the purpose of inducing the creditor to take a chance that the event proves to have been only imaginary. It is when things go wrong that the security comes into its own. Any security that will not stand up in case of insolvency of the debtor is only a trap for the unwary creditor. Of all the tests to which a security transaction can be put, bankruptcy is the most exacting. This is as it should be.

MacLachlan, The Impact of Bankruptcy on Secured Transactions, 60 ColvM. L. REv. 593, 608 (1960). 
By contrast, the watchword of the unsecured creditor is "equality in distribution."104 The unsecured creditor wants all of the bankrupt's creditors-whatever their status prior to bankruptcy-to help bear the financial burden of their common debtor's collapse. Many short-term trade creditors find it difficult to obtain security for their advances: yet they too have contributed to their debtor's estate. Their claims deserve protection, especially against the all-devouring after-acquired property clause which allows a secured party to take a blanket lien on all of his debtor's future assets and then to sit back, supremely confident that he will be sitting on a mountain of collateral on bankruptcy day. ${ }^{105}$ The trustee, who represents the bankrupt's unsecured creditors, has the power to avoid certain transfers as preferential to prevent such inequities and, to the extent that it is fair and commercially feasible, to advance the Bankruptcy Act's basic aim of equality in distributing the bankrupt's assets.

Section $4-607(\mathrm{~d})^{106}$ represents a compromise between these two positions. It recognizes the validity of security interests in after-acquired inventory and receivables, but places a limit on the extent to which such interests will be protected. The trustee is to determine the value of the collateral securing the debt three months prior to the date of bankruptcy, or, "if new value was first given under the security agreement during the three-month period, on the date new value was first given"; if the debt was under-collateralized at that time any increase in the value of the collateral, due to the acquisition by the debtor of new inventory or receivables, during the period prior to bankruptcy, will constitute a voidable preference recoverable by the trustee acting under section 4-607(a).

Thus if a debt of $\$ 100,000$ is secured three months prior to bankruptcy by inventory worth $\$ 75,000$, and the value of the inventory increases during the three-month period to $\$ 100,000$ at the time the petition is filed, the trustee can retain or recover

104 'Equality is equity' is a beguiling slogan. In the context of bankruptcy proceeding, ideal equality might seem to lie in having all creditors share equally, without regard to their pre-bankruptcy status. The Bankruptcy Act did not go-could not, it may be, constitutionally have gone-that far. Nevertheless, bankruptcy law has always inclined in that direction.

2 GILMORE, supra note $6, \S 45.2$, at 1287.

1051970 Committer RePORT, supra note 6, at 6.

${ }^{106}$ For the text of the section, H.R. 31, 94th Cong., 1st Sess. $\$ 4-607$ (d) (1975), see note 7 supra. 
$\$ 25,000$ worth of inventory as a preference. If, three months prior to bankruptcy or at the time during that period when new value was first given, the value of the collateral equaled or exceeded the value of the debt that it secured, no preference exists under this test. ${ }^{107}$ Fluctuations in the value of the collateral during the period between the two temporal points employed by the section 4-607(d) yardstick, are irrelevant as to whether and to what extent a preference has been given to the secured party. If a debt first becomes under-collateralized during this period, but once again is fully collateralized at the time of bankruptcy, no voidable preference has been given.

This compromise solution is based on the policy judgment that the Article 9 floating lien is beneficial in that it makes it easier and less expensive for a businessman to borrow on his inventory and receivables. ${ }^{108}$ The floating lien particularly benefits the new or under-capitalized business whose available collateral is likely to consist of "quick" or "current" assets. ${ }^{109}$ Furthermore, the floating lien on after-acquired inventory or receivables is not wholly prejudicial to the debtor's unsecured creditors. They have a more vital interest than the debtor's secured creditors in the continuing health of the debtor's business, ${ }^{110}$ and the floating lien permits the debtor to obtain

${ }^{107}$ The "two-point" measuring test is triggered only when the debt is undercollateralized at the first of the two temporal points employed by the test.

${ }^{108}$ The Gilmore Committee itself characterized the policy underlying the two-point measuring test as follows:

The policy ... sacrifices a great deal to simplicity of administration. It seeks to avoid complicated and expensive litigation by focusing the judicial inquiry on the situation as it existed on the two dates chosen as measuring points. It seeks to catch in the preference net particularly those situations in which the transferee (as by crash sales of inventory below cost to feed the receivables) has sought to manipulate the pre-bankruptcy situation to his own advantage. (In the normal course of a business declining into bankruptcy the position of an inventory or receivables lender, far from improving, will almost certainly deteriorate). 1970 COMMITTEE RePORT, supra note 6, at 16-17.

The Committee stated earlier that the two-point test was designed to implement the view

that there is no preference, provided that the relevant security agreement has been properly perfected, so long as the secured party has not improved his position during the pre-bankruptcy period (or, to state the case the other way around, so long as there has been no net depletion of the debtor's estate).

1970 CommitTeE RePort, supra note 8, at 15. In this regard, the Committee apparently relied on the rationale adopted by the "net result" cases, see note 58 supra.

${ }^{109}$ Kripke, supra note 28, at 507; MacLachlan, supra note 103, at 607-08.

110 In the long run (not necessarily in any particular case), the unsecured trade creditor is benefited by secured credit, because it converts inventory which 
more cheaply the secured credit needed to keep his business alive during difficult periods.

The floating lien, however, should not receive unlimited protection. In particular, there are two situations in which a secured party should not be permitted to claim as collateral for his loan the full value, measured on the date of bankruptcy, of the inventory or receivables securing it.

First, a secured party obviously should be denied rights in his collateral to the extent that the value of such collateral increased, during the period immediately preceding bankruptcy, because of his own fraudulent or manipulative conduct.111 $\mathrm{A}$ creditor whose loan is secured by receivables sometimes uses his power or influence to persuade his debtor to conduct a "fire sale" of all available inventory at prices well below cost, in order to "pump" the receivables and thereby swell the value of the collateral securing his loan. Such a creditor gains an unfair advantage over the debtor's other creditors, secured as well as unsecured, and diminishes the total value of the bankrupt's estate. Conduct of this sort should be discouraged.

Secondly, and not as obviously, a secured party should be denied the benefit of any "windfall" increase in the value of his collateral during the immediate pre-bankruptcy period. Such a windfall could result from an unexpected and extraordinary flurry of sales which dramatically increased the total value of the outstanding receivables. Since the secured party did not bargain for a windfall of this type, he has not given anything to the debtor's estate, by way of consideration, that might entitle him to appropriate to himself the entire benefit of the windfall. ${ }^{112} \mathrm{~A}$ windfall increase in the value of the bankrupt's estate should benefit all creditors equally so that the consequences of the vicissitudes of commercial life will be moderated rather than exaggerated in bankruptcy.

might not be sold for months and receivables which might not be collected for months into cash. It enables the debtor to pay his trade credit bills, perhaps to discount them. Overall, trade creditors are aided although in a particular case they may be distressed because the dividend in bankruptcy is small.

Krause, Kripke \& Seligson, supra note 58, at 287.

111970 COMMITTEe RePORT, supra note 6, at 16-17. An increase in the value of the creditor's collateral, due to conduct of this sort, closely resembles a classical fraudulent conveyance, which not even the warmest friend of the Article 9 floating lien is likely to defend. See generally note 4 supra.

${ }_{112}$ This conclusion follows as a corollary to the "net result" rule, see note 58 supra. 
The policy of protecting the floating lien on after-acquired inventory and receivables in all but the two situations just described is best served by focusing not on the state of mind of the secured party, ${ }^{113}$ or on the technical chronology of each transfer, but rather on fluctuation in the overall value of the collateral securing the floating lien. ${ }^{114}$ In almost all cases, the total value of the debtor's inventory and receivables will decline in the period preceding bankruptcy. ${ }^{115}$ When it increases instead, the increase will almost always be due to manipulative conduct by the secured party or a windfall outside "the normal course of a business declining into bankruptcy."116

This presumption, like all others, does not hold true in every case. Weaving the preference net more finely to catch the distinction between "good" and "bad" increases in the value of collateral would, however, require refinement of the two-point net improvement test that would undoubtedly make proving the existence of a voidable preference more difficult. This difficulty would increase the likelihood of "tedious, asset-exhausting litigation"117 that would only deplete the estate. In sum, there must be "a straight policy choice between the rough and ready provisions of [section 4-607(d)] (which, it is thought, will work reasonably well in all but the unusual case) and the desire to do justice case by case." 118

This argument is well put. As the draftsmen themselves recognized, ${ }^{119}$ however, the two-point test embodied in section 4-607(d) would condemn many "improvements of position" whose increase was due neither to manipulative conduct on the

${ }^{113}$ The present Bankruptcy Act focuses on state of mind by making a preferential transfer voidable by the bankrupt's trustee "if the creditor receiving it or to be benefited thereby or his agent acting with reference thereto has, at the time when the transfer is made, reasonable cause to believe that the debtor is insolvent." Section 60b, 11 U.S.C. § 96(b) (1970). For the historical evolution of this aspect of the law of voidable preferences, see note 4 supra.

1141967 COMMITTEe REPORT, supra note 8, at 15.

1151970 Committee Report, supra note 6, at 17.

${ }^{116} I d$.

${ }^{117}$ Id.

${ }^{118} I d$.

${ }^{119}$ It is easy to state hypothetical (and real) cases in which there has been an "improvement of position" within the proposed statutory text where there has been no fraud or manipulation by the transferee-for example, the case of an agricultural loan where the crop is harvested and processed just before bankId. ruptcy. 
part of the secured party nor to a windfall gain outside the normal course of business. Such "improvements" would occur, for example, in most seasonal industries, in which the volume of inventory and receivables fluctuates dramatically but regularly during the course of the business year. ${ }^{120}$

Imagine the situation, under section 4-607(d), of a secured party who makes a loan to a toy manufacturer in November and takes as collateral the manufacturer's receivables, including those to arise in the future. When he makes the loan, the secured party may not be disturbed that his loan is presently undercollateralized; he anticipates that a rapid but normal expansion in the volume of his debtor's receivables during the holiday season will bring the value of the collateral up to the amount of the loan. The near certainty of such an expansion is part of the consideration inducing the secured party to make his loan in the first place. The expansion is not an unanticipated and unbargained-for windfall. ${ }^{121}$ Nevertheless, when the manufacturer files a bankruptcy petition in January, the lender will learn, much to his dismay, that he has received a voidable preference which the manufacturer's trustee is empowered to recover for the benefit of the bankrupt's unsecured creditors.

This result seems unfair and is certainly inconsistent with

${ }^{120}$ Professor Hogan has described the special problems that a two-point net improvement test poses for seasonal industries:

Although this "two point" method of tracing makes for easier administration than either precise tracing or revival of the policing techniques of Benedict $v$. Ratner, it has a discriminatory premise. Only businesses that have a regular and constant flow of accounts or inventory can safely be financed within its boundaries. If the debtor has fluctuating income, his credit needs will be poorly served. Farmers may thus have an added obstacle to overcome in obtaining credit, because their accounts are earned en masse at the end of the growing season. Other seasonal industries, such as toy manufacturers, suppliers of recreational items, and fashion clothiers, may face this same problem. In addition, expanding businesses in need of capital will find the preference hurdle in their path. Each of these cases involves a situation in which, without any scheme to harm creditors, the value of the accounts may increase during the four months prior to bankruptcy. And in each case, the secured creditor may have planned on the rising accounts as collateral without violating any standard of business morality. If we adopt the "two point" method of tracing as a flat rule, we may reach a workable compromise between the claims of the secured creditor group and the bankruptcy bar. But, without any other reason, we will be discriminating against a substantial number of debtors and their secured creditors.

Hogan, supra note 56, at 564-65. See also Krause, Kripke \& Seligson, supra note 58, at 287.

121 Neither is the seasonal expansion the result of fraud or manipulation by the secured party. 
the policy underlying section 4-607(d). ${ }^{122}$ The two-point net improvement test should be modified to avoid the result in this case without significantly increasing the likelihood of expensive and time-consuming litigation in cases in which a true preference has been given and should be set aside.

One new approach would be to state the basic premise of section 4-607(d) in the form of an explicit but rebuttable presumption. The premise is, of course, that "[i]n the normal course of a business declining into bankruptcy the position of an inventory or receivables lender, far from improving, will almost certainly deteriorate." ${ }^{23}$ The trustee would be entitled to rely on the presumption, but a secured party could rebut it in the unusual case in which his improvement in position was entirely attributable to events occurring in the normal and anticipated course of his debtor's business. ${ }^{124}$ To this end, section 4-607(d) might be redrafted in the following manner:

122 See note 108 supra.

1231970 Committee Report, supra note 6, at 17 (emphasis supplied).

${ }^{124}$ The proposed Bankruptcy Act that was introduced in the Canadian House of Commons on May 5, 1975, Bill C-60, 30th Parl., 1st Sess. 23 \& 24 Eliz. II (1974-75), contains a section treating preferences at "arm's length." The section reads as follows:

158. (1) A transfer that is a preference in favour of a creditor at arm's length is unenforceable against the trustee where the transfer is made

(a) less than six months before the filing of a petition;

(b) when the debtor is insolvent or is unable to pay his debts; and

(c) other than in the normal course of affairs or, to the knowledge of the creditor, other than in the normal course of the affairs of the debtor.

(2) For the purpose of subsection (1), a transfer made less than three months prior to the date of filing of a petition is deemed to have been made otherwise than in the normal course of affairs unless the contrary is proved.

In $\S 2$ of the Bill a preference is defined as

a transfer made or allowed by a debtor to, or for the benefit of, a creditor for or on account of an antecedent debt, the effect of which transfer, if not set aside, is to allow the creditor to receive a greater percentage of that debt than he would otherwise receive under this Act .....

The Canadian treatment of the "arm's length" (that is, non-fraudulent) preference is distinguished by the explicit fashion in which it incorporates the "normal course of affairs" test that is merely implicit in § 4-607 of the proposed American Act. According to one of the Canadian draftsmen, "[T]he sections in the Bill relating to voidable preferences are strongly influenced by the report made by Professor Gilmore's Committee to the National Bankruptcy Conference." Letter from John Honsberger, Esq., to the author, June 18, 1975, on file with the University of Pennsylvania Law Review.

In Canada, "floating charges have not been attacked as preferential if the amount of inventory charged fluctuates during the suspect period." Id. As a result, there was no perceived need to include in the Canadian Bill a specific section comparable to $\S$ 4-607(d). Nevertheless, the idea directly expressed in $\$ 158(2)$ of the Canadian Bill bears a strong similarity to the implicit presumption on which $\S 4-607$ (d) rests. 
If inventory was acquired or receivables arose and became collateral covered by a security agreement, a perfected transfer of such inventory or receivables or the proceeds of either is not voidable except to the extent that the transferee has improved his position by an increase in the value of the security at the expense of the estate. The transferee shall be presumed to have so improved his position at the expense of the estate if:

1) the debt secured exceeds the aggregate value of all security for the debt three months before the filing of the petition or, if new value was first given under the security agreement during the three-month period, on the date new value was first given; and

2) the amount by which the debt exceeded the value of the security has been reduced or eliminated by the date of the petition.

For the secured party, this formulation is more attractive. It lets him argue that although he has improved his position under the two-point test, the improvement has not been at the expense of the estate. In making this argument, however, the secured party will bear the burden of proof: this burden will help reduce the incidence of frivilous or pro forma challenges to the trustee's exercise of his avoiding powers. The trustee's position will be further enhanced, and litigation reduced, by elimination of the provision in section 4-607(d)(2), as presently drafted, that "[t]he trustee shall have the burden of proving an improvement in position by an increase in the value of security at the expense of the estate and the extent thereof." The likelihood of litigation in cases in which a secured party's improvement of position is due to an unexpected windfall or manipulative conduct would not seem to be dramatically increased by making the two-point test a presumption rather than an iron-clad rule.

This formulation of section 4-607(d) has some difficulties. Perhaps its most important shortcoming is that it is not at all clear what a secured party would have to establish to overcome the presumption that he had improved his position at the expense of the bankrupt's estate. By turning the two-point test into a presumption, the assumption is introduced that at least some improvements of position, as defined by the test, are not "at the expense of the estate." The conclusion required by the policy underlying section 4-607(d) is that improvements not attributable to a windfall or to manipulation by the secured party, but 
occurring in the ordinary and expected course of the debtor's business, are not improvements at the expense of the estate.

To reduce this proposition to precise statutory language would be difficult, however; and such a reduction, even if possible, might not be desirable. The better approach would be to leave the question open for judicial consideration on a case-bycase basis. Although this would stimulate more litigation, at least initially, than would the hard and fast rule of present section 4-607(d), it is not unreasonable to think that the courts would quickly isolate a few situations (the seasonal industry, the crop loan, and so forth) as legitimate exceptions to the general rule that any improvement of position by an inventory or receivables lender during the three months prior to bankruptcy is at the expense of his debtor's estate. ${ }^{\mathbf{1 2 5}}$

A second, but less serious, difficulty with the proposed reformulation of section 4-607(d) is that it seems to allow, or at least not rule out, a trustee's setting aside a perfected transfer, on the grounds that it improved the position of the transferee at the expense of the estate, even when the improvement did not fall within the strictures of the two-point test. This possibility follows from the fact that the proposed reformulation is cast in the form of a presumption. ${ }^{126}$ Thus, nothing in the language of the reformulation would prevent a trustee from asserting that a secured debt was under-collateralized four months prior to the filing of the petition (though it was fully collateralized three months prior); that the debtor was continuously insolvent for the four months; and that the improvement was therefore at the expense of the estate. The three-month period of section (d) is not a necessary condition, and is independent of the threemonth period of section (a).

Obviously, a line should be drawn somewhere. The draftsmen of section 4-607(d) have chosen to draw it at a point

${ }^{125}$ Obviously, the more flexible we make the test for determining improvement "at the expense of the estate," the more we stir up additional litigation. So far as the redraft proposed here is concerned, the costs in added litigation will be high, if at all, only in the short run. In any case they will be offset by the advantages to be gained from stating the improvement test as a rebuttable presumption rather than an irrebuttable rule.

${ }^{126}$ Logically, this has two consequences: (1) Not all transfers that fall within the strictures of the two-point test are necessarily preferences; and (2) some transfers that fall outside the strictures of the two-point test may be considered preferences. The purpose of the further amendment to $\S 4-607$ (d) which is offered above is to rule out the second result while preserving the first. 
three months before the filing of the petition. Although this line is an arbitrary one, ${ }^{127}$ it should be respected; the trustee should not be permitted to set aside a transfer that improved the position of a secured creditor at the expense of the bankrupt's estate as long as the improvement occurred prior to the three-month period, provided, of course, that the transfer is not otherwise voidable under section $4-607(\mathrm{a})(2){ }^{128}$ The small benefit that would accrue to general creditors from an indefinite period is overshadowed by the increased uncertainty and risk for secured creditors and the consequent increased cost of credit. The trustee can be foreclosed from attacking improvements beyond the three-month limit by the addition of a sentence to the proposed reformulation of section 4-607(d):

For purposes of this subsection a transferee does not improve his position at the expense of the estate as a result of any change in the value of the collateral under a security agreement if such change occurs more than three months before the filing of the petition.

\section{Improvements Due to Appreciation in Value}

What is the proper treatment, in bankruptcy, of improvements in a secured party's position that are attributable not to the debtor's acquisition of new inventory or receivables, but rather to an appreciation in the value of collateral in which the debtor already has rights? This question is obviously related to the one discussed above, because appreciation in value ${ }^{129}$ may be viewed as a species of after-acquired property. Although the question has attracted considerable scholarly attention, ${ }^{130}$ it has

${ }^{127}$ In an earlier draft, the line was drawn at four months. The Committee's comment $a$ propos its choice of a four-month period seems to fit equally well its final choice of a three-month period:

There is no logical reason why the four-months period should be used for this purpose instead of a shorter period or a longer one. On the other hand, there is no reason to believe that a longer or shorter period would better serve the ends of justice or better promote the underlying policy of the Bankruptcy Act.

1967 COMMITTEE REPORT, supra note 8 , at 15.

${ }^{128}$ Under the proposed Act, "insiders" could be subjected to odd results as their "preference period" is one year but their "improvement" period is three months.

129 The expression "appreciation in value" will be used throughout to refer specifically to any increase in the value of collateral in which the debtor already has rights.

${ }^{130}$ See, e.g., Letter from Professor Homer Kripke to the Committee on the Coordination of the Uniform Commercial Code and the Bankruptcy Act, Sept. 17, 1970, in COMMISSION REPORT, supra note 3, at 210; Hogan, supra note 56, at 558-59; Krause, 
provoked almost no litigation. ${ }^{131}$ This lack of litigation is rather puzzling. The question could arise in a variety of perfectly routine, real-world situations, for example, when the market value of inventory securing a debt increases rapidly during the immediate pre-bankruptcy period, or when the value of raw materials securing a debt increases during a process of manufacture or assembly.

Despite the fact that the question has so far remained an academic one, the draftsmen of section 4-607 attempted at first

Kripke \& Seligson, supra note 58, at 290; Note, After-Acquired Property Security Interests in Bankruptcy: A Substitution of Collateral Defense of the UCC, 77 YALE L.J. 139, 153 (1967).

${ }^{131}$ In his letter to the Gilmore Committee, supra note 130, Professor Kripke cites the case of Meinhard, Greeff \& Co. v. Edens, 189 F.2d 792 (4th Cir. 1951), as a model for the proper treatment in bankruptcy of appreciation value due to completion of work in process. Meinhard involved the reorganization of a corporation under Chapter X of the Bankruptcy Act. The corporation, a manufacturer of cotton textile, borrowed money from Meinhard, Greeff \& Co., a textile factor. As security for its loan, Meinhard took a lien, under the South Carolina Factor's Lien Act, "upon the merchandise and accounts receivable of [the] debtor including all cotton and cotton yarn in process of manufacture." Id. at 796. When the corporation's petition for reorganization was filed, a quantity of its cotton was in the course of manufacture. The reorganization court ordered the corporation's trustees to finish the cotton and sell it, which they did. The cotton was sold for $\$ 71,254.65$. The cost incurred by the trustees in completing its manufacture was $\$ 25,106.99$. The referee, assuming the cotton in process had only waste value, held that the trustees and Meinhard had become joint venturers in the continued operation of the mill. He then awarded Meinhard half the difference between sale price and "fully allocated" costs, only $\$ 14,031,20$. The Fourth Circuit rejected this theory and held for Meinhard:

Expenditures made by the trustees in completing the manufacture were, of course, properly chargeable against the product; but there is nothing in law or in reason to justify treating the yarn in process as waste and the amount received for it when the manufacturing process was completed as profit resulting from the manufacture. It was not waste if the claimant was entitled to have the manufacture go forward, and claimant was entitled to this if the mills were operated under order of court, since it was the duty of the court to protect the rights of all persons having interests in the property, not merely the interests of the debtor or general creditors. If the debtor had continued the operation of the mills, the entire proceeds of the yarn would have been subject to claimant's lien. When the trustees continued the operation and took over the yarn, they did so subject to claimant's rights and may not charge against the proceeds anything in excess of the expenditures properly attributable to completing the manufacture. Id. at 796-97.

Professor Kripke acknowledged that Meinhard was concerned with an appreciation in value that occurred after the filing of the petition (and, it should be noted, in a reorganization proceeding), but suggested that the Meinhard rule would be equally applicable when the secured party's improvement in position occurred before the petition was filed (and when the debtor's estate was being liquidated rather than rehabilitated).

That Professor Kripke had to go so far afield to find case support for his position is itself evidence of the meagerness of litigation concerning the proper bankruptcy treatment of appreciation value. 
to answer it. ${ }^{132}$ Their answer was contained in a separate section of the 1967 proposed redraft of section $60,{ }^{133}$ which was subsequently eliminated. ${ }^{134}$ That section provided, in essence, that any increase during the pre-petition period in the value of collateral, in which there was a perfected security interest, does not constitute a preference, if the increase in the value of the collateral was due to:

(1) fluctuating market values; or

(2) the conversion of inventory or other property into receivables by disposition of the property by the debtor in the ordinary course of his business; or

(3) the manufacture or assembly of raw materials, work in progress or component parts into a product, except to the extent that property not subject to the security agreement was, during the four month period, incorporated in the product. ${ }^{135}$

Apparently, the committee's initial view was that an improvement in the position of a secured party due to appreciation in the value of his collateral should be treated more favorably in bankruptcy than a comparable improvement due to acquisition by the debtor of new inventory or receivables. Appreciation in value was to be insulated from attack by the trustee, while improvement by acquisition was to be stigmatized as preferential to the extent that it ran afoul of the two-point net improvement test. ${ }^{136}$ The committee seems to have believed, early in its deliberations, that this special treatment of appreciation value was "consistent with what scattered case law there is,"137 and harmonized well with the Article 9 provisions concerning security interests in "proceeds," ${ }^{138}$ accessions, and processed or manufac-

1321967 Committe RePoRt, supra note 8, at 18-19.

133 Id.

134 1970 Commitree RePort, supra note 6, at 18. The Committee's reversal of position, between 1967 and 1970, is most dramatically evidenced by its changing attitude toward the holding in Rockmore v. Lehman, 129 F.2d 892 (2d Cir. 1942), cert. denied, 317 U.S. 700 (1943). In 1967, the Committee felt that its position codified the holding in that case. 1967 Commitee RePoRT, supra note 8, at 16. By 1970, however, the Committee admitted that its new position with respect to the treatment of appreciation value may have overruled Rockmore. 1970 Committe RePORT, supra, at 18.

1351967 CommtTeE REPORT, supra note 8, at 18.

${ }^{136}$ See notes 79-86 supra \& accompanying text.

1371967 Commitee RePORT, supra note 8, at 18.

${ }^{138}$ Unifora Commercial CoDE $\S 9-306$. Although the draft of the revision of $\S 60$ adopted the rule that "a change in the form of collateral (as when inventory is converted 
tured goods. ${ }^{139}$

The Committee ultimately reversed itself and eliminated the original provision protecting improvements of position due to appreciation in the value of collateral. Improvements of this type are accorded a distinctly unfavorable treatment under proposed section 4-607 and under the revised 1970 draft upon which the section is based. Any improvement in the secured party's position due to appreciation in the value of his collateral would presumably be vulnerable under section $4-607(a),{ }^{140}$ and the appreciation would receive protection from the section 4-607(d) exception only if the collateral is inventory that has been "acquired" or receivables that have "arisen" or proceeds therefrom, and even then only to the extent such improvement was not at the expense of the estate as defined or presumed by the Act. That this result was a deliberate one is shown by the following hypothetical posed by the Committee in its 1970 report to the Bankruptcy Conference:

into receivables) is not necessarily preferential even when the result of the conversion is an increase in value," it did not take an explicit position "on the validity in bankruptcy proceedings of [Uniform Commercial] Code § 9-306(4)." 1967 CommrtreE RePORT, supra note 8 , at 18 . The draftsmen noted that

The validity of this Code provision (like that of its predecessor, $\S 10$ of the Uniform Trust Receipts Act) has been a matter of some controversy. The failure of the Draft to take a position merely reflects the fact that the Committee has not yet considered whether it would be desirable to add a provision to deal with the \$ 9-306(4) problem.

Id. 18-19. For articles on the bankruptcy treatment of the Article 9 security interest in proceeds, see note 12 supra.

${ }^{139}$ UNIFORM Commercial COdE $\$ \S 9-314,9-315$. In pertinent part, $\$ 9-315(1)$ now states:

If a security interest in goods was perfected and subsequently the goods or a part thereof have become part of a product or mass, the security interest continues in the product or mass if

(a) the goods are so manufactured, processed, assembled or commingled that their identity is lost in the product or mass; or

(b) a financing statement covering the original goods also covers the product into which the goods have been manufactured, processed, or assembled.

${ }^{140}$ The security interest consists of a bundle of rights including contingent interests defined by the value of the subject matter of the interest. If the value changes, different interests, by definition, emerge. Unless a new entity theory is invoked, $c f$. notes $56 \& 57$ supra \& accompanying text, the debtor has rights in the appreciated portion of the property only when appreciation actually takes place. The transfer of the security interest including those rights can only "occur," for purposes of the proposed Act, when appreciation takes place. See notes $86-94$ supra \& accompanying text. Therefore, any increment in value of the subject matter of a security interest will be a transfer for antecedent debt and may be vulnerable to avoidance under $\$ 4-607$ (a). 
Let it be assumed that a secured party's collateral four months before bankruptcy consists of raw materials worth $\$ 10,000$. On the date the bankruptcy petition is filed the raw materials have been converted into finished products worth $\$ 20,000$. (Under Code 9-315 the security interest in the raw materials carries through to the finished product.) Assuming an initial "deficiency" (the debt secured, let us assume, was at all times $\$ 25,000$ ), the $\$ 10,000$ increase in value is not protected under sub-paragraph IV [current subsection (d)] and goes to the trustee. ${ }^{141}$

Unfortunately, the reasons for this dramatic reversal in the Committee's position do not appear anywhere in its report, and we are left to speculate about the Committee's motives. ${ }^{142}$ Matters are made even worse by the official Commission commentary on the proposed revision of section 60 , which suggests that section 4-607(d) is, in effect, to be read as embodying the Committee's original view that improvements due to appreciation should be treated more favorably than those due to the acquisition of new collateral. With regard to the section 4-607(d) net improvement test, the Commission commented:

Improvement in position is alone not enough. The trustee must also establish that the improvement was at the expense of the estate. This is intended partially to meet Professor Kripke's criticism that increases in value of collateral due to, e.g., harvesting crops, completing work in progress, sales of inventory, and seasonal fluctuations in value, would constitute improvement in position and be recoverable. ${ }^{143}$

"At the expense of the estate" is to be construed, according to the Commission, as imposing an additional element of proof upon the trustee which will have the effect of insulating from attack as a preference any improvement in the position of a secured creditor due to appreciation in the value of already exist-

1411970 Commrttee RePort, supra note 6, at 18.

${ }^{142}$ It is Professor Gilmore's recollection that the Committee's decision to drop the section that explicitly outlined the treatment of appreciation value was based upon a feeling that as the question had not come up in litigation, the best policy was to let "sleeping dogs lie" by not creating a legal problem that did not yet exist. Interview with Professor Gilmore in New Haven, Connecticut, Apr. 16, 1975.

${ }^{143}$ Commission RePort, supra note 3, at 209-10. 
ing collateral (whether through manufacture, transformation into "proceeds," or fluctuating market prices), despite the fact that the improvement would otherwise be voidable under the two-point test.

The Commission's suggested reading of section 4-607(d) leaves the proposed treatment of appreciation value in bankruptcy proceedings in a state of intolerable confusion. A clear solution to the problem of appreciation value is required. In seeking such a solution, we should begin by asking why an improvement in the position of a secured creditor, wholly attributable to an increase in the value of his collateral during the period immediately preceding bankruptcy, should be protected from attack by his debtor's trustee.

The real goal of the section 4-607(d) two-point net improvement test is to facilitate the recovery, by the trustee, of benefits flowing to secured creditors as a result either of unanticipated windfall gains or the creditors' own manipulative conduct. ${ }^{144}$ The test assumes that any improvement in a secured creditor's position during the immediate pre-bankruptcy period will be inconsistent with the normal course of a business declining into insolvency and, therefore, attributable in all likelihood to one of these two causes.

By implication, an improvement due to an event or events within the normal and expected course of the debtor's business should not be stigmatized as preferential. It is reasonable to assume that the certain or near-certain prospect of such an improvement constituted part of the consideration inducing the secured party to make his loan or to set its terms as he did. The secured party may be assumed to have given something to his debtor's estate in exchange for the high probability that the value of his collateral would increase in the normal course of his debtor's business. This distinguishes the situation from a windfall gain, for which the secured party has given nothing. The logic of this argument applies equally to increases flowing from the debtor's acquisition of new collateral and to appreciation in the value of collateral already held by the debtor.

Consider the following example. On November 1, a bank lends $\$ 100,000$ to a manufacturer of cotton thread and perfects a security interest in the manufacturer's inventory on the same

${ }^{144}$ Notes 108-112 supra \& accompanying text. 
date. ${ }^{145}$ When the loan is made the inventory consists entirely of raw, unprocessed cotton worth $\$ 50,000$. By December 1 , the raw cotton has been worked into finished thread whose value is $\$ 175,000$. No competing security interests exist in the finished thread. ${ }^{146}$ Before selling the thread, the manufacturer is petitioned into bankruptcy. ${ }^{147}$ The bank enters a secured claim for $\$ 100,000$; the bankrupt's trustee seeks to avoid this claim to the extent of $\$ 50,000$, which he claims is a voidable preference.

The increase in the value of the inventory securing the loan probably does not represent an unanticipated windfall benefit to the bank. The bank undoubtedly expected that the raw cotton which secured its loan would soon be processed into finished thread, in the normal course of the debtor's business, and that as a result it would increase in value. Otherwise the bank might very well have refused to make the loan at all, especially if the debtor lacked other collateral sufficient to secure its debt. The manufacturer needed $\$ 100,000$ on November 1 to complete the processing of his raw cotton. His short-term trade creditors benefited from the loan. ${ }^{148}$ The manufacturer's trustee in bankruptcy should not be permitted to treat the bank's improvement in position as a windfall benefit reaped at the expense of the manufacturer's unsecured creditors.

Not all improvements of position due to appreciation in the value of collateral should be treated alike. An improvement that results from an unbargained-for windfall should be stigmatized as preferential; one that results from a routine and expected increase in value should be insulated from attack by the trustee. This conclusion accords with the policy underlying section 4-607(d)'s proposed treatment of security interests in afteracquired inventory and receivables.

Of the three types of appreciation value treated in the Committee's original draft proposal, ${ }^{149}$ only' one-appreciation

${ }^{145} \mathrm{He}$ perfects his security interest by filing a financing statement as required by UNIFORM COMMERCIAL CODE $§ 9-302$.

${ }^{146}$ If others existed, the priority among them would be fixed according to UNIFORM Commercial Code $\$ 9-315(2)$ :

When under subsection (1) more than one security interest attaches to the product or mass, they rank equally according to the ratio that the cost of the goods to which each interest originally attached bears to the cost of the total product or mass.

${ }^{147}$ See $\S 3 \mathrm{~b}$ of the Bankruptcy Act, 11 U.S.C. § 21(b) (1970).

${ }^{148}$ See note 110 supra.

${ }^{149}$ See text accompanying note 135 supra. 
due to "the manufacture or assembly of raw materials, work in progress," and so forth-appears to fall clearly within the category deserving insulation from attack. ${ }^{150}$ Appreciation because of "fluctuating market values" or "the conversion of inventory or other property into receivables" presents a more ambiguous case, ${ }^{151}$ and may fall in either category, depending, for example, upon whether the market fluctuation is seasonal and predictable or irregular and unanticipated.

Taking into consideration difficulties of proof and the general goal of streamlining bankruptcy litigation, ${ }^{152}$ a fair compromise might be to protect, without qualification, any appreciation in the value of collateral due to its manufacture or assembly, but to give the trustee the advantage of a presumption that any appreciation due to fluctuating market values or the conversion of inventory into "proceeds" is "at the expense of the estate" and hence recoverable. ${ }^{153}$ This would constitute a clear and equitable treatment of appreciation value in bankruptcy proceedings. To achieve this result, an additional subsection should be added to section 4-607, which would read as follows:

Although property transferred for security increases in value during the three months before the filing of the petition initiating a proceeding under this Act, such a transfer is not voidable, provided it was perfected either before the beginning of the three-month period or at the time of the transfer of the property, except to the extent that the increase in value is at the expense of the estate. Such an increase shall be presumed to be at the expense of the estate if it is the result of

(1) fluctuating market values; or

(2) the conversion of inventory or other property into receivables by disposition of the property by the debtor in the ordinary course of his business.

150 Appreciation of this sort is quite regular and may be predicted in advance. It therefore seems reasonable to assume that it constitutes part of the consideration inducing a secured party to make his loan on the specific terms that he does, inducing him, for example, to give a more favorable credit term or a lower interest rate than he otherwise might.

151 These cases are more ambiguous because the appreciation involved is usually less predictable and therefore less likely to have been within the contemplation of the parties at the time they negotiated the loan.

${ }^{152} C f$. note 108 supra.

${ }^{153}$ Of course, all the other elements of a preference must also be present. 
An increase in the value of property transferred for security is not at the expense of the estate if it is the result of

(1) the manufacture or assembly of raw materials, work in progress, or component parts into a product.

As with the modification of section 4-607(d), this proposal does not fully define "at the expense of the estate" and leaves the phrase's definition to case-by-case consideration. The category of increases at the expense of the estate does not include all increases that would benefit the estate if set aside. This negative implication may be drawn from the section's last sentence, which deems as not "at the expense" appreciation by manufacture of the subject matter of the secured interest. Nor is the phrase restricted to the value of assets originally part of the estate and free and clear of the security interest, as the presumption against fluctuating market prices demonstrates.

\section{Section 4-607 and the Corporate Indenture}

Corporate bonds and debentures are typically issued under an indenture of trust which contains a clause providing that certain specified types of after-acquired property are to be subjected to the mortgage securing the bonds or debentures in question. ${ }^{154}$ In the past, long-term corporate debt invariably was secured by the corporation's fixed or long-term assets, such as its equipment or the securities of another corporation. As a rule, "quick" or "current" corporate assets, such as inventory and receivables, were used as collateral in short-term financings only. ${ }^{155}$

${ }^{154}$ H. Guthmann and H. Dougall, Corporate Financial Policy 183-86 (4th ed. 1962). See generally Coogan \& Bok, The Impact of Article 9 of the Uniform Commercial Code on the Corporate Indenture, 69 YALE L.J. 203 (1959).

155 Professor Gilmore attributes this phenomenon to the application of the rule of Benedict v. Ratner, 268 U.S. 353 (1925):

The complexities of complying with the Benedict rule made receivables the most inappropriate of collateral for bonds issued under a trust indenture. Inclusion of the receivables, indeed, was not merely inappropriate but dangerous: one aspect of the Benedict rule was that if there was a failure of compliance with respect to a part of the collateral, the result was to void the transaction with respect to all the collateral. In the pre-Benedict cases, it is not uncommon to find provisions in corporate indentures under which the security reserved for the bonds included the receivables as well as the fixed assets such as plant and equipment. After Benedict such inclusion could well have been fatal. Thus another aspect of the "professionalization" which resulted from Benedict was that 
Article 9, by repealing the rule of Benedict $v$. Ratner, ${ }^{156}$ has apparently removed the main reason for segregating the collateral pools for long- and short-term financings, as corporations have done for the last half century. More importantly, Article 9 offers no grounds for believing that an after-acquired security interest in a long-term asset, such as a large and relatively immobile piece of industrial machinery, is any more or less vulnerable to attack as a voidable preference under present section 60 of the Bankruptcy Act than an after-acquired security interest in inventory or receivables. Neither Article 9 nor the present Bankruptcy Act distinguishes between types of after-acquired property in terms of the long- or short-term nature of the property involved. Admittedly, all the cases holding the properly perfected transfer of an Article 9 security interest in after-acquired property to be non-preferential under section 60 involved either inventory or receivables. No consideration of logic or policy, however, would bar the extension of these holdings, especially that of DuBay $v$. Williams, ${ }^{157}$ to a case involving a security interest in industrial machinery or other long-term assets when the interest attached under the after-acquired property clause in a corporate indenture. A security interest of this kind should easily survive any post-DuBay challenges as a voidable preference under section 60 .

Under section 4-607 of the proposed Act, however, the status of a security interest in after-acquired property other than inventory or receivables is, to say the least, uncertain. ${ }^{158}$ Assume, for example, that corporation $A B C$ issues a series of bond secured by a mortgage on all of the corporation's industrial equipment, including any that may be acquired after issuance of

receivables, like inventory, were divorced from long-term financing of the corporate indenture type and became a domain reserved for specialists.

1 Gilmore, supra note $6, \S 8.1$, at 253. See note 27 supra.

156 UNiform Commercial Code $\$$ 9-205, Comment 1.

157417 F.2d 1277 (9th Cir. 1969). For a discussion of DuBay, see note 69 supra.

158 This appears to have been recognized by the draftsmen:

[U]nder the Draft after-acquired property interests in collateral other than inventory and receivables would be subject to avoidance as preferential unless the secured party gave new value at the time of the acquisition or made an enabling advance. . . . No doubt further thought should be given to the problem of regular course of business acquisitions by a corporation which has issued bonds or debentures under an indenture of trust which contains an after-acquired property clause.

1967 Committee Report, supra note 8, at 17. 
the bonds, and that counsel for the corporation and the indenture trustee make a proper Article 9 filing. One year later, $A B C$ acquires a new machine, which immediately becomes subject to the mortgage securing the bonds. Two months after acquiring the machine, $A B C$ is petitioned into bankruptcy. The trustee asserts that the bondholders' security interest in the after-acquired machine constitutes a voidable preference, which should be set aside in favor of $A B C$ 's trade creditors and stockholders.

The bondholder's security interest in the after-acquired machine was given by $A B C$ in satisfaction of an antecedent debt. ${ }^{159}$ Because the transfer occurred within three months of $A B C$ 's bankruptcy and, let us assume, while $A B C$ was insolvent, it may be avoided by a trustee exercising his general power of recovery under section 4-607(a), unless it falls within one of the exceptions enumerated in subsections (b), (c) or (d).

On its face, section 4-607(b) ${ }^{160}$ does not appear to be relevant. Section 4-607(c) ${ }^{161}$ might provide some protection for the bondholders if they could convince the referee that the money $A B C$ acquired when it originally sold its bonds was intended to be applied to the purchase of new machinery, including the particular machine involved here. This would be difficult to prove. Unless the bondholders could trace the expenditure of the money (even though section 4-607(c) does not actually impose a tracing requirement), ${ }^{162}$ they probably would be unable to overcome the trustee's predictable assertion that the money was not given to enable $A B C$ to purchase new machinery, but rather to

${ }^{159}$ See notes 95-99 supra \& accompanying text.

${ }^{160}$ For the text of H.R. 31, 94th Cong., 1st Sess. § 4-607(b), see note 7 supra.

${ }^{161}$ For the text of H.R. 31, 94th Cong., 1st Sess. \$ 4-607(c), see note 7 supra.

${ }^{162}$ In this respect, $\S 4-607$ (c) differs from the definition of a "purchase money security interest" in \$ 9-107 of the Uniform Commercial Code. In commenting on the predecessor of present $\S 4-607$ (c), the Gilmore Committee stated that:

[T] his provision is somewhat broader than the Code definition of "purchase money security interest" ( $\$ 9-107)$ which, with respect to purchase money interests taken by lenders (as distinguished from sellers), requires not only that the new value be given to enable the acquisition but that the value "be in fact so used". In the Committee's opinion, no useful purpose would be served, in the context of $\S 60$, by maintaining the tracing requirement which is inherent in the Code "in fact so used" provision. To entitle the transferee to the protection given new value financing, it seems sufficient to require a showing that the advance was made as an enabling advance and that the acquisition of the property followed within a reasonable time.

1967 COMMITTEE REPORT, supra note 8, at 14. 
finance an entirely new venture or to liquidate old debts. At best, the bondholders are likely to find the going under section 4-607(c) rather rugged.

Section 4-607(d) offers no relief either as it applies only to receivables and inventory. Indeed, the trustee could argue, with some plausibility, that because the section 4-607(d) exception is specifically limited to these two kinds of after-acquired property, the draftsmen obviously intended to make all other kinds subject to the general rule stated in section 4-607(a).

$A B C$ 's bondholders do not fit within any of the explicit statutory exceptions; consequently, their best (or only) defense may be to employ one or another common law theory to argue that despite what section 4-607 says, their security interest in the after-acquired machine was not transferred for an antecedent debt at all. They could use either the "entity" theory, ${ }^{163}$ claiming that the transfer really occurred when the original debt was incurred; or the "substitution of collateral" theory, ${ }^{164}$ claiming that the debt was really incurred when the transfer of the afteracquired property took place. Neither theory is appropriate in the context of the proposed Act. ${ }^{165}$ The entity theory, positing as it does a constant stream of similar items, is particularly inappropriate. ${ }^{166}$ Presumably, $A B C$ acquires new machines (as long as it is not in the business of selling them) only at irregular intervals. There is no reason to believe that $A B C$ sells its old machines, if it sells them at all, at or about the time it acquires new ones. The entity theory cannot be made to fit the factual pattern prevalent in the acquisition of long-term assets. Neither this theory nor the substitution of collateral theory can be exploited by $A B C$ 's bondholders to support the assertion that their interest in $A B C$ 's new machine is non-preferential.

If the proposed revision of section 60 is enacted, security interests in after-acquired corporate assets other than inventory and receivables will be vulnerable to attack as preferential transfers. This result, which would reverse the treatment of such interests under the present version of section 60 , is undesirable. Of course, a security interest in an after-acquired long-term asset should be voidable to the extent that it results from a windfall

\footnotetext{
${ }^{163}$ See notes 56 \& 57 supra \& accompanying text.

${ }^{164}$ See note 58 supra \& accompanying text.

${ }^{165}$ See note 94 supra.

16615 U.C.L.A.L. REv. 678, 697 (1968).
} 
gain or manipulative conduct by the secured party-for the same reasons, and only the same reasons, that a similar security interest in receivables or inventory should be voidable. "Windfall" might be given a more expansive meaning in this context, to include acquisitions made in connection with new ventures or capital expansions that depart from the ordinary course of the debtor-corporation's business as it existed when the bonds were originally issued. In general, however, an "ordinary course of business test" which makes sense and seems fair in the case of inventory and receivables, should be applied to the kind of long-term assets that frequently secure corporate obligations.

After-acquired security interests in long- and short-term assets should be treated equally. If section 4-607 is enacted in its present form, it may upset established and desirable patterns of corporate financing. This result can be avoided, and long-term assets put on a par with inventory and receivables, by redrafting the first sentence of section 4-607(d) as follows:

(d) Exception: After-Acquired Property. If property was acquired by the debtor and became collateral covered by a security agreement, a perfected transfer of such property or the proceeds thereof is not voidable except to the extent that the transferee has improved his position by an increase in the value of the security at the expense of the estate.

\section{Conclusion}

Section 4-607 of the proposed Bankruptcy Act attempts to provide a simple, yet fair, framework for determining the validity, in bankruptcy proceedings, of security interests in afteracquired property. Because this was the "most difficult problem which the [drafting] Committee . . . wrestled with during the several years of its labors," 167 it ought not to come as a surprise, nor to be a cause for rebuke, that the attempt has been less than wholly successful.

This Article has suggested four specific ways in which section 4-607 may be improved: (1) sections 4-607(g)(1), (6), and (7) should be redrafted to make clear that the transfer of a security

${ }^{167} 1970$ COMMITTEE REPOR', supra note 6 , at 2. 
interest in after-acquired inventory or receivables is a transfer for antecedent debt, recoverable by a trustee acting under section 4-607(a); (2) section 4-607(d) should be redrafted to state its underlying premise in the form of an explicit presumption against improvements in position, rebuttable in the unusual case in which a secured party's improvement in position is entirely attributable to events occurring in the normal and anticipated course of his debtur's business; (3) a new subsection should be added to section 4-607 which explicitly deals with the treatment of appreciation value, that is, with improvements in the position of a secured party due not to the debtor's acquisition of fresh inventory or receivables, but rather to an increase in the value of collateral in which the debtor already has rights; and (4) section 4-607(d) should be redrafted to ensure equal treatment of longand short-term assets.

These changes would not alter dramatically the main policy or conceptual structure of section 4-607. They would, however, remove residual inequities and help clarify the general principle that informs, or ought to inform, the law of voidable preferences as it applies to security interests in after-acquired property.

To conclude, let us restate this principle: The transfer of a security interest in after-acquired property, made within some fixed period immediately preceding bankruptcy and while the debtor is insolvent, ought to be voidable if it is the result of a windfall gain or of overreaching on the part of the secured party. The secured party has contributed nothing to the estate entitling him alone to appropriate the benefit of a windfall, and he should not be permitted to profit from an act of wrongdoing that depletes the debtor's estate. It is a fair presumption, but only a presumption, that any increase in the value of the collateral that occurs during the period immediately preceding bankruptcy is due to one of these two causes. An improvement in the position of a secured party that results from an increase in the value of his collateral during this period should therefore be presumed, with certain specific exceptions, to be a preference. Unless the secured party can demonstrate that his improved position is not attributable to a windfall or to overreaching, but to events wholly within the ordinary course of his debtor's business, the improvement should be recoverable by his debtor's trustee in bankruptcy. 
This basic idea is implicit in the net improvement test of section 4-607(d). ${ }^{168}$ The changes recommended here make the idea explicit and attempt to apply it throughout the range of problems that section 4-607(d) purports to cover. If these changes represent an improvement, it is not because consistency is a virtue in itself, but because the underlying idea is a good one.

${ }^{168}$ See note 108 supra. 